\title{
Aging Management of Nuclear Power Plant Containments for License Renewal
}

Manuscript Completed: September 1997

Date Published: September 1997

W. C. Liu, P. T. Kuo, S. S. Lee

Division of Reactor Program Management

Office of Nuclear Reactor Regulation U.S. Nuclear Regulatory Commission

Washington, DC 20555-0001

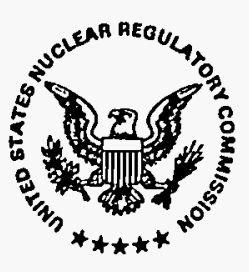




\section{DISCLAIMIER}

Portions of this document may be illegible in electronic image products. Images are produced from the best available original dociment. 


\section{DISCLAIMER}

This report was prepared as an account of work sponsored by an agency of the United States Government. Neither the United States Government nor any agency thereof, nor any of their employees, make any warranty, express or implied, or assumes any legal liability or responsibility for the accuracy, completeness, or usefulness of any information, apparatus, product, or process disclosed, or represents that its use would not infringe privately owned rights. Reference herein to any specific commercial product, process, or service by trade name, trademark, manufacturer, or otherwise does not necessarily constitute or imply its endorsement, recommendation, or favoring by the United States Government or any agency thereof. The views and opinions of authors expressed herein do not necessarily state or reflect those of the United States Government or any agency thereof. 


\section{ABSTRACT}

The Nuclear Regulatory Commission (NRC) published its license renewal rule, Title 10 of the Code of Federal Regulations (10 CFR) Part 54, on May 8, 1995, providing the requirements for renewal of operating licenses for nuclear power plants. 10 CFR 54.21(a)(1)(i) requires an aging management review of containment structures to ensure that the effects of aging will be managed so that their intended functions will be maintained for the period of extended operation. In 1990, the Nuclear Management and Resources Council (NUMARC), now the Nuclear Energy Institute (NEI), submitted for NRC review, the industry reports (IRs), NUMARC Report 90-01 and NUMARC Report 90-10, addressing aging management issues associated with PWR containments and BWR containments for license renewal, respectively.

Recently, the Commission amended 10 CFR 50.55a to promulgate requirements for inservice inspection of containment structures. The final rule on $\$ 50.55 \mathrm{a}$, "Codes and Standards for Nuclear Power Plants; Subsection IWE and Subsection IWL," was published in August 1996. This rule incorporates by reference the 1992 Edition with the 1992 Addenda of Subsections IWE and IWL of Section XI, Division 1, of the American Society of Mechanical Engineers (ASME) Boiler and Pressure Vessel Code addressing the inservice inspection of metal containments/liners and concrete containments, respectively.

The purpose of this report is to reconcile the technical information and agreements resulting from the NUMARC IR reviews and the inservice inspection requirements of Subsections IWE and IWL as promulgated in $\$ 50.55 \mathrm{a}$ for 1 icense renewal consideration. This report concludes that Subsections IWE and IWL of Section XI, Division 1 , of the ASME Code as endorsed in $\$ 50.55 \mathrm{a}$ are generally consistent with the technical information and agreements reached during the IR reviews. Specific exceptions are identified and additional evaluations and augmented inspection activities for renewal are recommended. 


\section{CONTENTS}

Page

ABSTRACT

ABBREVIATIONS

vii

LIST OF TABLES

ix

1. INTRODUCTION

2. LICENSE RENEWAL EVALUATION OF AGING MANAGEMENT OF CONTAINMENT STRUCTURES

3. CONCLUSIONS

REFERENCES

\section{TABLES}

1. AGING MANAGEMENT OF PWR CONTAINMENTS FOR LICENSE RENEWAL $\ldots \ldots \ldots$

2. AgING MANAGEMENT OF BWR CONTAINMENTS FOR LICENSE RENEWAL $\ldots \ldots \ldots 27$

\section{APPENDICES}

A IMPLEMENTATION HIGHLIGHTS OF SUBSECTIONS IWE AND IWL THROUGH 10 CFR $50.55 \mathrm{a}$

B LIST OF PWR CONTAINMENT COMPONENTS

C LIST OF BWR CONTAINMENT COMPONENTS 



\section{ABBREVIATIONS}

ACI American Concrete Institute

AISC American Institute of Steel Construction

ARDM Age-Related Degradation Mechanism

ASME American Society of Mechanical Engineers

ASTM American Society for Testing and Materials

BWR Boiling Water Reactor

CS Carbon Stee1

CFR Code of Federal Regulations

CRD Control Rod Drive

ECCS Emergency Core Cooling System

GSI Generic Safety Issues

IR Industry Report

ISI Inservice Inspection

IWE Subsection of ASME Code, Section XI, "Rules for Inservice Inspection of Nuclear Power Plant Components," containing "Requirements for Class MC and Metallic Liners of Class CC Components of Light-Water Cooled Plants"

IWF Subsection of ASME Code, Section XI, "RuTes for Inservice Inspection of Nuclear Power Plant Components," containing "Requirements for Class 1, 2, 3, and MC Component Supports of Light-Water Cooled Plants"

IWL Subsection of ASME Code, Section XI, "RuTes for Inservice Inspection of Nuclear Power Plant Components," containing "Requirements for Class CC Concrete Components of Light-Water Cooled Plants"

$\begin{array}{ll}\text { NEI } & \begin{array}{l}\text { Nuclear Energy Institute } \\ \text { NRC }\end{array} \\ \text { NUMARC } & \text { Nuclear Regulatory Commission } \\ \text { ppm } & \begin{array}{l}\text { Parts per million } \\ \text { PWR }\end{array} \\ \text { Pressurized Water Reactor } \\ \text { RG } & \text { Regulatory Guide } \\ \text { SS } & \text { Stainless Steel } \\ \text { SCC } & \text { Stress Corrosion Cracking }\end{array}$


$\ldots \ldots$ 
TABLE 1. AGING MANAGEMENT OF PWR CONTAINMENTS FOR LICENSE RENEWAL

Page

Concrete \& Steel Containment One-time Inspection.............. 7

Concrete Structure - Aging Mechanisms

Freeze-Thaw .................................... 8

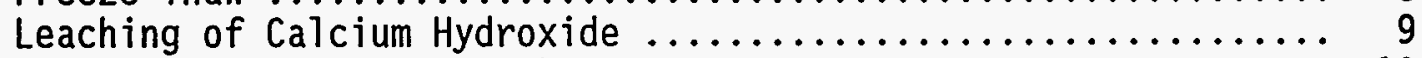

Aggressive Chemical Attack .......................... 10

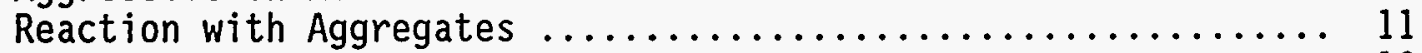

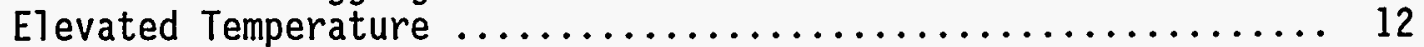

Irradiation of Concrete $\ldots \ldots \ldots \ldots \ldots \ldots \ldots \ldots \ldots \ldots \ldots \ldots \ldots \ldots \ldots \ldots \ldots, 12$

Concrete Interaction with Aluminum $\ldots \ldots \ldots \ldots \ldots \ldots \ldots \ldots, 13$

Structural Steel \& Liner - Aging Mechanisms

Corrosion ....................................... 14

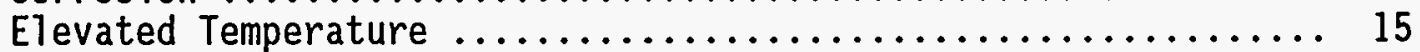

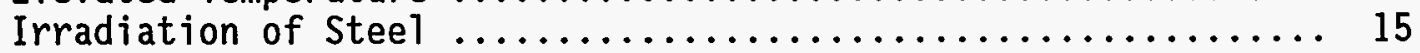

Stress Corrosion Cracking ............................... 16

Reinforcing Steel - Aging Mechanism

Corrosion of Embedded Steel $\ldots \ldots \ldots \ldots \ldots \ldots \ldots \ldots \ldots \ldots \ldots \ldots \ldots$

Reinforcing Steel \& Prestressing Tendons - Aging Mechanisms

Elevated Temperature ................................ 18

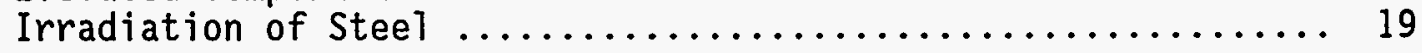

Containment Structures \& Components - Aging Mechanism

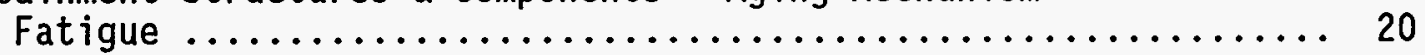

Containment Structure \& Its Concrete Basemat - Aging Mechanisms

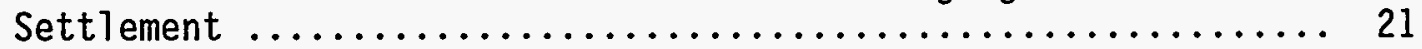

Erosion of Cement $\ldots \ldots \ldots \ldots \ldots \ldots \ldots \ldots \ldots \ldots \ldots \ldots \ldots \ldots \ldots \ldots, 22$

Containment Structure \& Its Components - Aging Mechanism

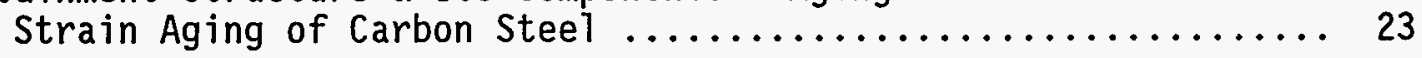

Concrete Containment Prestressing Tendons - Aging Mechanisms Stress Relaxation of Prestressing Wire, Shrinkage Creep,

Anchorage Seating Losses, and Tendon Friction ............. 24

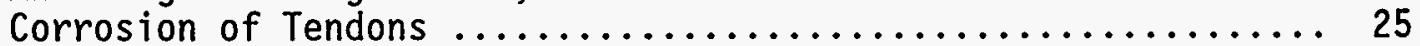

Containment Pressure Retaining Components - Aging Mechanism

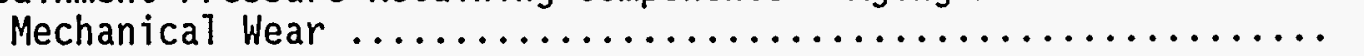


Table 2. AGING MANAGEMENT OF BWR CONTAINMENTS FOR LICENSE RENEWAL

Concrete \& Stee] Containment One-time Inspection............. 27

Concrete Structure - Aging Mechanisms

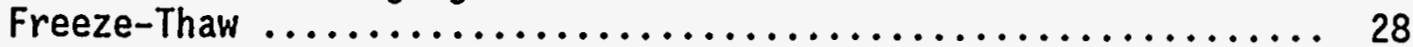

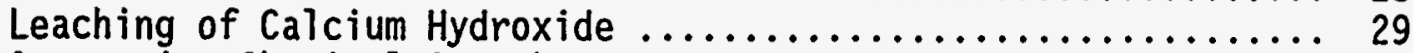

Aggressive Chemical Attack ......................... 30

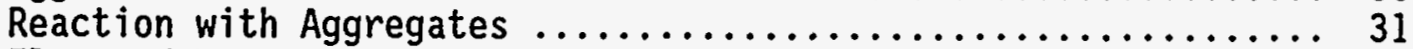

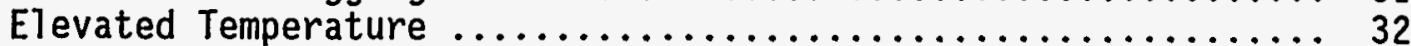

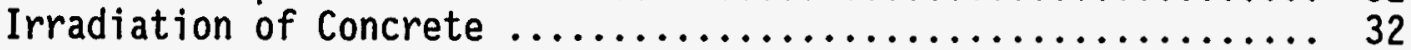

Structural Steel \& Liner - Aging Mechanisms

Atmospheric Corrosion ........................... 33

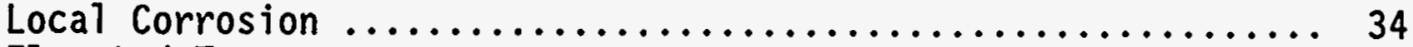

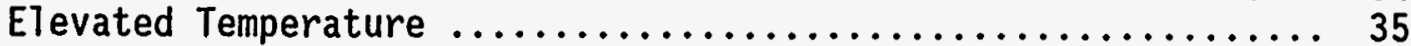

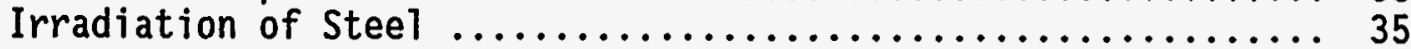

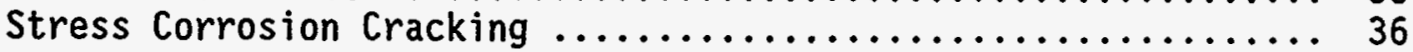

Reinforcing Stee1 (Rebar) - Aging Mechanism

Corrosion of Embedded Steet ...................... 37

Reinforcing Steel \& Prestressing Tendons - Aging Mechanisms

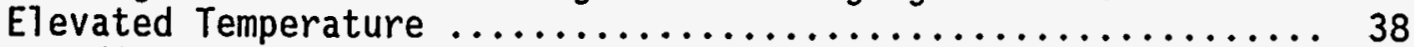

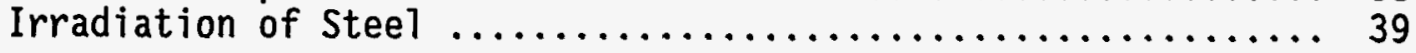

Containment Structures \& Components - Aging Mechanism

Fatigue

Containment Structure \& Its Concrete Basemat - Aging Mechanisms

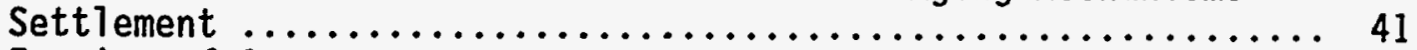

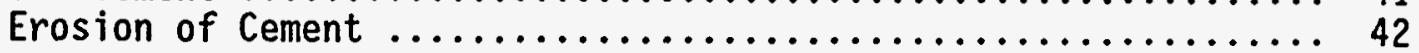

Containment Structure \& Its Components - Aging Mechanism

Strain Aging of Carbon Stee $\ldots \ldots \ldots \ldots \ldots \ldots \ldots \ldots \ldots . \ldots . \ldots 4$

Concrete Containment Prestressing Tendons - Aging Mechanisms

Stress Relaxation of Prestressing Wire, Shrinkage Creep,

Anchorage Seating Losses, and Tendon Friction ............ 44

Corrosion of Tendons .......................... 45

Containment Pressure Retaining Components - Aging Mechanism

Mechanical Wear ............................... 46 


\subsection{INTRODUCTION}

Part 54 of 10 CFR, the license renewal rule, was published on May 8, 1995, providing requirements for renewal of operating 1 icenses for nuclear power plants. 10 CFR 54.21(a)(1)(i) requires an aging management review of structures and components within the scope of 1 icense renewal to ensure that the effects of aging will be managed so that their intended functions will be maintained for the period of extended operation. Containment structures are subject to this requirement.

Recently, the Commission amended 10 CFR 50.55 a to promulgate requirements for inservice inspection of containment structures. The final rule on $\$ 50.55 \mathrm{a}$, "Codes and Standards for Nuclear Power Plants; Subsection IWE and Subsection IWL," was published on August 8, 1996 (61 FR 41303). This rule incorporates by reference the 1992 Edition with the 1992 Addenda of Subsections IWE and IWL of Section XI, Division 1, of the American Society of Mechanical Engineers (ASME) Boiler and Pressure Vessel Code addressing the inservice inspection of metal containments/liners and concrete containments, respectively [References 1 and 2]. Guidance for implementation of the containment inspection requirements is described in Appendix $A$ of this report.

In 1990, the Nuclear Management and Resources Council (NUMARC), now the Nuclear Energy Institute (NEI), submitted for NRC review, ten industry reports (IRs) addressing aging issues associated with specific structures and components of nuclear power plants for 1 icense renewal. Of the 10 IRs, one addresses PWR containments, and another addresses BWR containments [References 3 and 4]. No safety evaluations were developed for the review of these IRs. However, NUREG-1557 provides a brief summary of the technical information and NUMARC/NRC agreements resulting from the review of nine of the 10 IRs. The NUMARC Report 90-08, "Low-Voltage, In-Containment, Environmentally-qualified Cable License Renewal Industry Report, "[Reference 5] is not addressed in this NUREG since the subject is being addressed under GSI-168.

On August 26, 1996, the Commission issued Draft Regulatory Guide DG-1047, "Standard Format and Content for Applications to Renew Nuclear Power Plant Operating Licenses." for public comment as part of the implementation of 10 CFR Part 54, the license renewal rule. A comment was received concerning whether the NRC staff had any plans to 1 imit the scope of 1 icense renewal review for containments since the final rule on 10 CFR 50.55a, which endorses the 1992 Edition with the 1992 Addenda of Subsections IWE and IWL, was published on August 8, 1996. The purpose of this NUREG is to reconcile the technical information and agreements resulting from the NUMARC IR reviews and the inservice inspection requirements of Subsections IWE and IWL as promulgated in $\$ 50.55$ a for license renewal consideration.

\subsection{LICENSE RENEWAL EVALUATION OF AGING MANAGEMENT OF CONTAINMENT STRUCTURES}

The NRC staff reviewed Tables B3 and B4 of NUREG-1557 [Reference 5] for the PWR and BWR containments, respectively, to determine if Subsections IWE and IWL inspection requirements are consistent with the technical agreements from the IR reviews. Where NUREG-1557 indicates that an aging effect on specific 
structures is non-significant, the NRC staff recommends no aging management program. Where NUREG-1557 indicates that an aging effect is non-significant if certain conditions are met, the NRC staff reviewed Subsections IWE/IWL and $\$ 50.55 \mathrm{a}$ to determine if the containment inspection requirements would be adequate to manage that aging effect regardless of whether those conditions are met. Where NUREG-1557 indicates that an aging effect should be managed with specified programs, the NRC staff reviewed Subsections IWE/IWL and $\$ 50.55 \mathrm{a}$ requirements to determine if they are adequate to manage that aging effect for the renewal term. If the NRC staff determined that Subsections IWE/IWL and $\$ 50.55 \mathrm{a}$ requirements should be augmented to manage a certain aging effect for the renewal term, additional inspections or evaluations are recommended. The results of the NRC staff evaluation are provided in Tables 1 and 2 of this report for the PWR and BWR containments, respectively. The PWR and BWR containment structural components evaluated in NUREG-1557 are 1isted in Appendix B and Appendix C of this report, respectively.

\subsection{CONCLUSIONS}

The NRC staff has reconciled the technical information and agreements from the NUMARC IR reviews and the inspection requirements of Subsections IWE/IWL as promulgated in $\$ 50.55 \mathrm{a}$ for managing the effects of aging for PWR and BWR containments for the period of extended operation. The staff found that the requirements of Subsections IWE/IWL and $\$ 50.55 \mathrm{a}$ will be an effective aging management program for managing the aging effects of containment structures for the period of extended operation, provided that the following additional evaluations and inspections specifically for license renewal are also performed:

a. Specific requirements contained in Part 54, the 1 icense renewal rule, such as Part 54.4 for scoping and intended function, and Part 54.21 for evaluating time-limited aging analyses.

b. ASME Section XI, Appendix VII and Appendix VIII [References 6 and 7] to be implemented when uitrasonic examinations are utilized for inspection of containments.

c. The following issues, in addition to implementing Subsections IWE/IWL through $\$ 50.55 \mathrm{a}$, should be addressed in a license renewal application:

(1) Management of potential aging effects of structures in inaccessible areas when conditions in accessible areas may not indicate the presence of or result in degradation to such inaccessible areas. This is discussed in Items $1,3,4,9$, and 13 of Table 1 for PWR containments, and in Items 1, 3, 4, 9, and 13 of Table 2 for BWR containments of this report.

(2) Fatigue associated with containment penetration bellows and penetration sleeves. This is discussed in Item 16 of Table 1 for PWR containments, and in Item 16 of Table 2 for BWR containments of this report. 
(3) Settlement associated with containment concrete basemat bearing on soil or piles, or experiencing significant changes in ground water conditions. This is discussed in Item 17 of Table 1 for PWR containments, and in Item 17 of Table 2 for BWR containments of this report.

(4) Erosion of cement for porous concrete if subfoundation layers of porous concrete are used in the construction of containment concrete basemat with the presence of underground water. This is discussed in Item 18 of Table 1 for PWR containments, and in Item 18 of Table 2 for BWR containments of this report.

(5) Performance of examinations specified in Examination Category E-B for pressure retaining welds, and Examination Category E-F for pressure retaining dissimilar metal welds of Subsection IWE for license renewal. This is discussed in Item 12 of Table 1 for PWR containments, and Item 12 of Table 2 for BWR containments of this report.

(6) Cracking of penetration bellows. This is discussed in Item 12 of Table 1 for PWR containments, and Item 12 of Table 2 for BWR containments of this report.

(7) Elevated temperature of prestressing tendons for (prestressed) concrete containments. This is discussed in Item 14 of Table 1 for PWR containments, and Item 14 of Table 2 for BWR containments of this report.

The NRC staff recommends that the requirements of Subsections IWE and IWL through $\$ 50.55 \mathrm{a}$, and those items identified in sections 3.a. through 3.c. above be incorporated into the Standard Review Plan for License Renewal (SRP-LR). 


\section{REFERENCES}

1. Subsection IWE, "Requirements for Class MC and Metallic Liners of Class CC components of Light-Water Cooled Power Plants," Section XI, Division 1, Boiler and Pressure Vessel Code, American Society of Mechanical Engineers, New York, N.Y., 1992 Edition and 1992 Addenda.

2. Subsection IWL, "Requirements for Class CC Concrete Components of LightWater Cooled Power Plants," Section XI, Division 1, Boiler and Pressure Vessel Code, American Society of Mechanical Engineers, New York, N.Y., 1992 Edition and 1992 Addenda.

3. "Pressurized Water Reactor Containment Structures, License Renewa7 Industry Report," NUMARC Report Number 90-01, Revision 1, Nuclear Management and Resource Council, September 1991.

4. "BWR Containments, License Renewal Industry Report," NUMARC Report Number 90-10, Revision 1, Nuclear Management and Resource Counci1, December 1991.

5. NUREG-1557, "Summary of Technical Information and Agreements from Nuclear Management and Resources Council Industry Reports Addressing License Renewa1," U.S. Nuclear Regulatory Commission, October 1996.

6. Appendix VII, "Qualification of Nondestructive Examination Personnel for UTtrasonic Examination," Section XI, Division 1, Boiler and Pressure Vessel Code, American Society of Mechanical Engineers, New York, N.Y., 1989 Edition.

7. Appendix VIII, "Performance Demonstration for UItrasonic Examination Systems," Section XI, Division 1, Boiler and Pressure Vessel Code, American Society of Mechanical Engineers, New York, N.Y., 1989 Addenda.

8. NRC Information Notice 97-10, "Liner Plate Corrosion in Concrete Containments," March 13, 1997.

9. NRC Information Notice 97-11, "Cement Erosion from Containment Subfoundations at Nuclear Power Plants," March 21, 1997.

10. NRC Regulatory Guide 1.35, Revision 3, "Inservice Inspection of Ungrouted Tendons in Prestressed Concrete Containments, "July 1990.

11. ACI 201.2R-77, "Guide to Durable Concrete," American Concrete Institute.**

12. ACI 215R-74, "Consideration for Design of Concrete Structures Subjected to Fatigue Loading," American Concrete Institute.**

13. ACI 318, "Building Code Requirements for Reinforced Concrete," American Concrete Institute.** 


\section{REFERENCES (Continued)}

14. ACI 359, "Code for Concrete Reactor Vessel and Containments, "American Concrete Institute.**

15. NRC Information Notice 92-20, "Inadequate Local Leak Rate Testing, "March 3 , 1992.

16. Letter from T. F. Plunkett of the Florida Power and Light Company to Stewart D. Ebneter of NRC, dated January 25, 1993.

**: denotes that the citation is used as a reference to provide only background information. 


$$
\cdots \quad \ldots
$$


TABLE 1. AGING MANAGEMENT OF PWR CONTAINMENTS FOR LICENSE RENEWAL

\begin{tabular}{|c|c|c|}
\hline Item & $\begin{array}{l}\text { Component, Aging } \\
\text { Mechanism \& Aging } \\
\text { Effects }\end{array}$ & Issue and Evaluation" \\
\hline 01 & $\begin{array}{l}\frac{\text { Concrete \& Steel }}{\text { Containment }} \\
\text { Aging mechanism: } \\
\text { Not applicable. } \\
\text { Aging effects: } \\
\text { General }\end{array}$ & 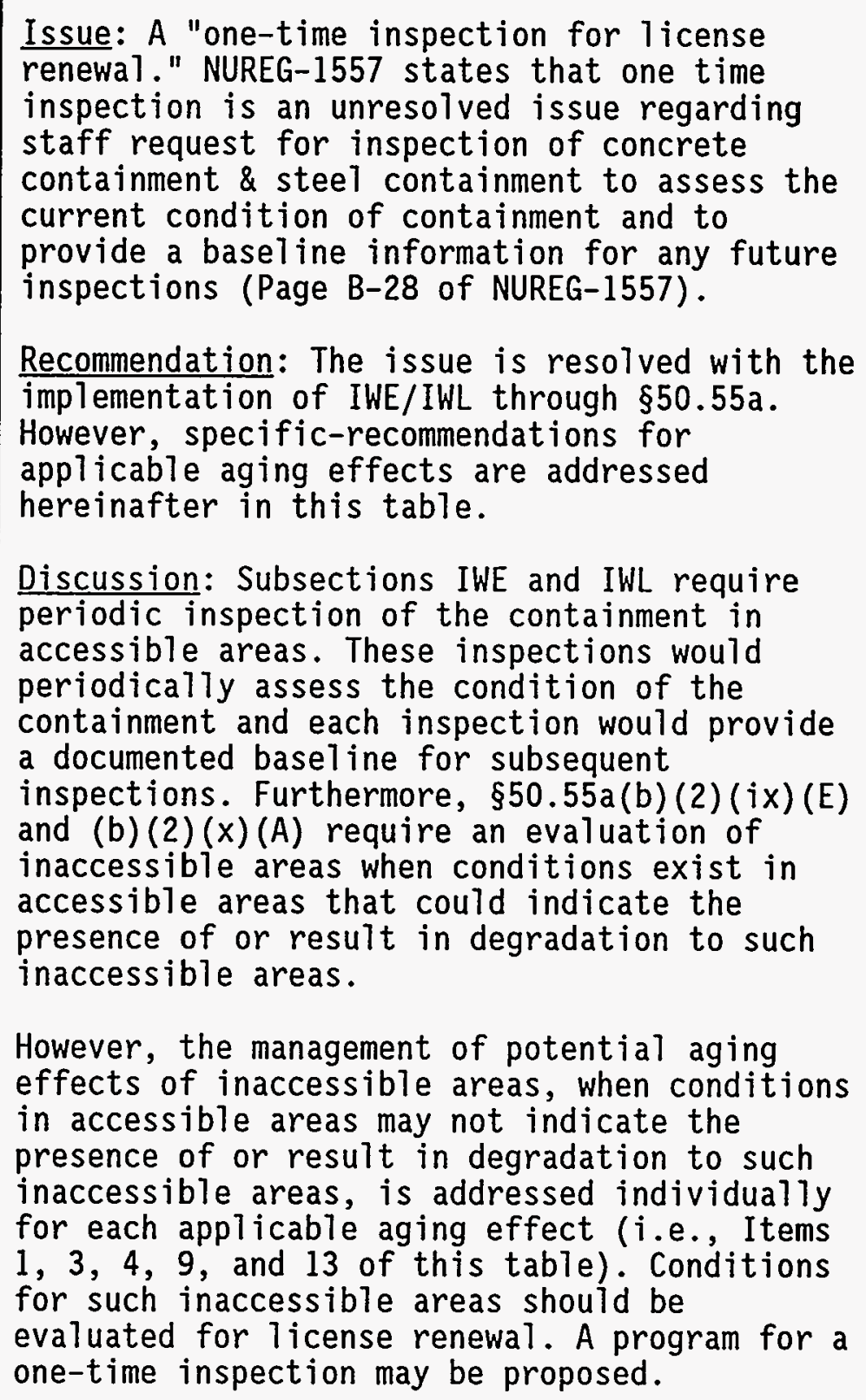 \\
\hline
\end{tabular}




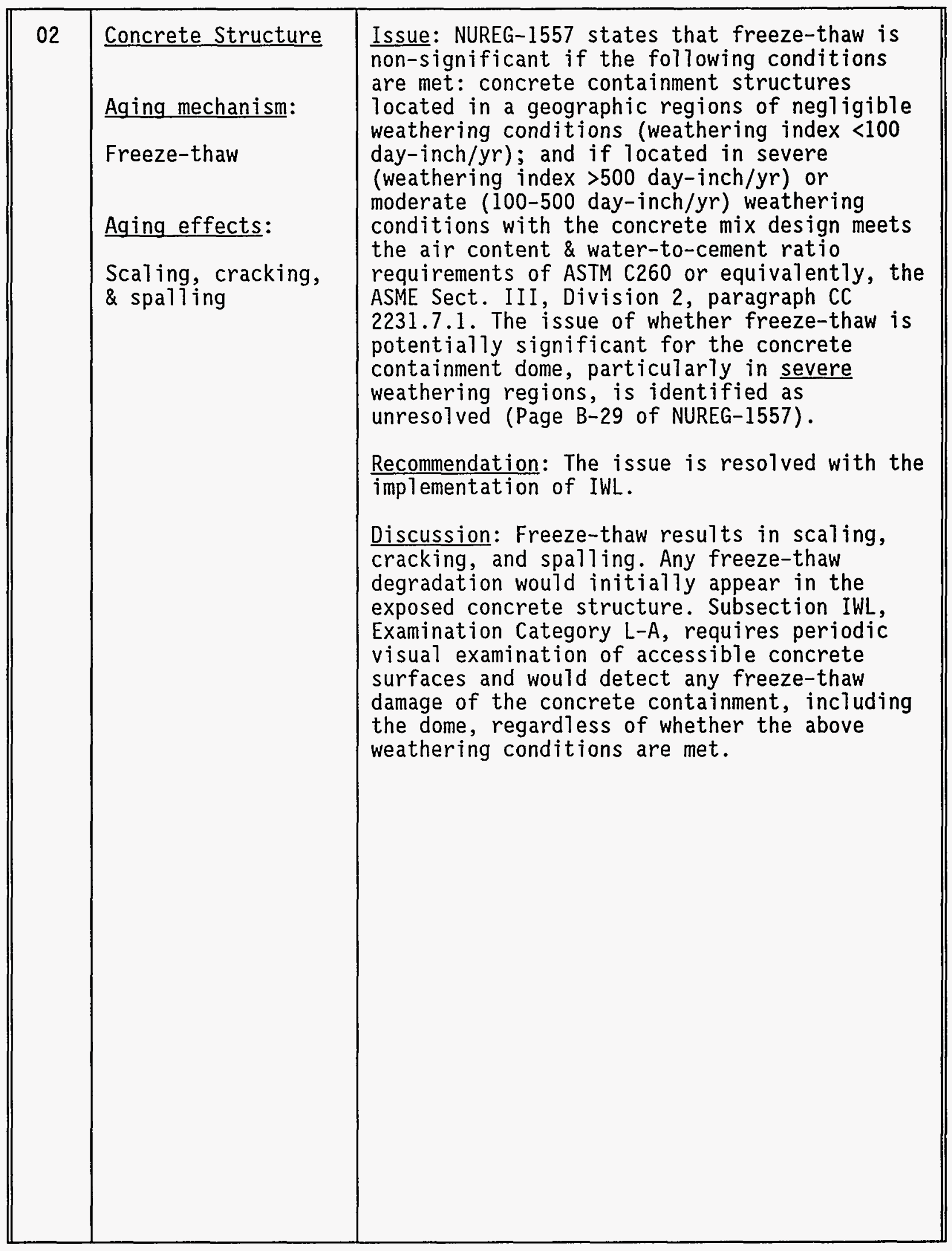




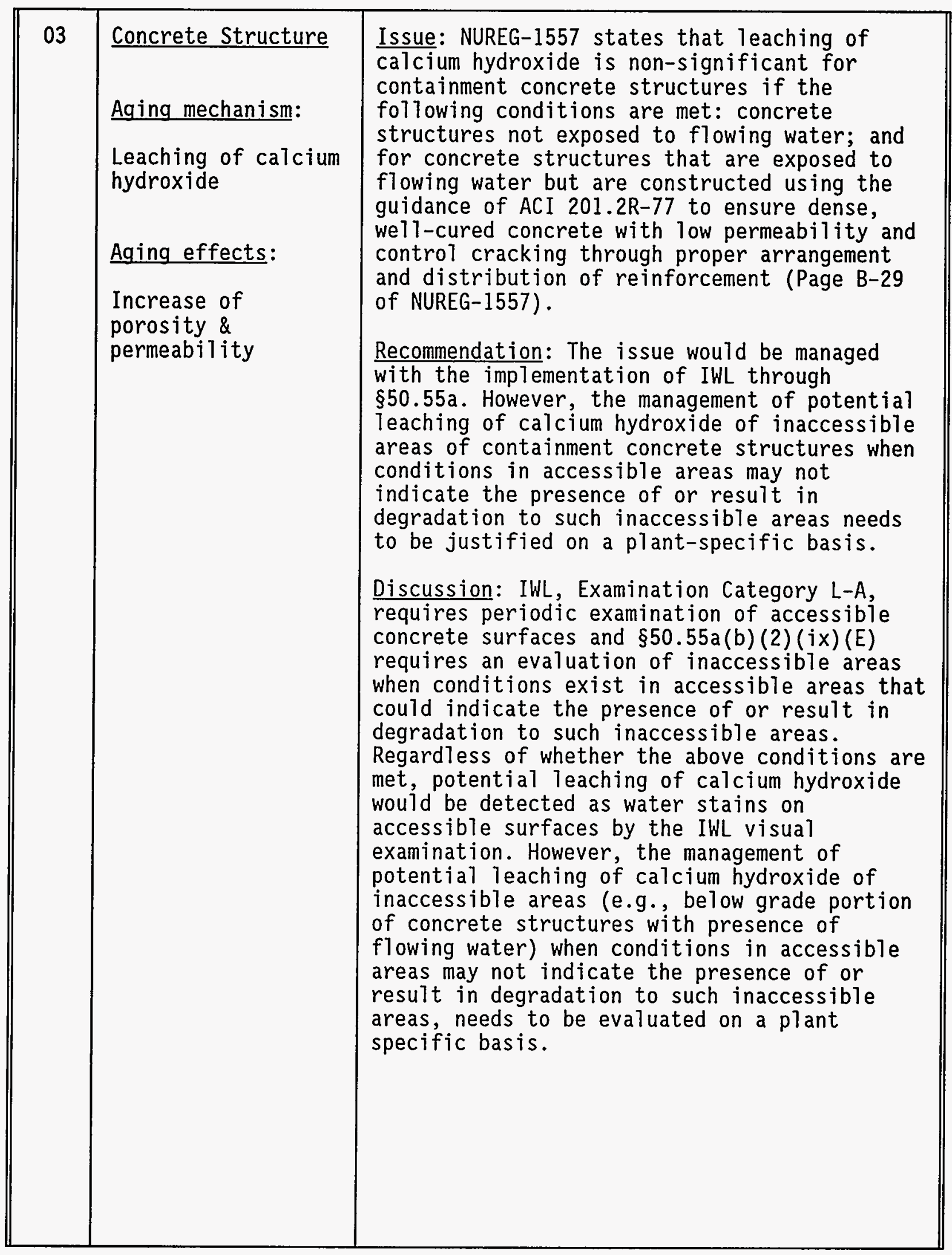




\begin{tabular}{|c|c|c|}
\hline 04 & $\begin{array}{l}\text { Concrete Structure } \\
\text { Aging mechanism: } \\
\text { Aggressive chemical } \\
\text { attack } \\
\text { Aging effects: } \\
\text { Increase of } \\
\text { porosity and } \\
\text { permeability, } \\
\text { cracking, and } \\
\text { spalling }\end{array}$ & $\begin{array}{l}\text { Issue: NUREG-I557 states that aggressive } \\
\text { chemical attack is non-significant for above } \\
\text { grade concrete containment structures because } \\
\text { they are not exposed to ground water. } \\
\text { Aggressive chemical attack is non-significant } \\
\text { for below grade concrete containment } \\
\text { structures if the following conditions are } \\
\text { met: containment concrete is not exposed to } \\
\text { aggressive ground water (pH } 5.5 \text {, chloride } \\
\text { >500 ppm, \& sulfate >1500 ppm); or if exposed } \\
\text { to ground water that exceeds the pH, chloride, } \\
\text { sulfate limits, the exposure is for } \\
\text { intermittent periods only. NUREG-1557 } \\
\text { indicates that inspection of concrete } \\
\text { containment structure should be in accordance } \\
\text { with IWL. NUREG-1557 states that evaluation } \\
\text { for management of inaccessible areas of below } \\
\text { grade concrete containment structures is to be } \\
\text { justified on a plant-specific basis (Page B-30 } \\
\text { of NUREG-1557). } \\
\text { Recommendation: The issue would be managed } \\
\text { with the implementation of IWL through } \\
\text { §50.55a. However, the management of potential } \\
\text { aggressive chemical attack of inaccessible } \\
\text { areas of containment concrete structures when } \\
\text { conditions in accessible areas may not } \\
\text { indicate the presence of or result in } \\
\text { degradation to such inaccessible areas needs } \\
\text { to be justified on a plant-specific basis. } \\
\text { Discussion: Aggressive chemical attack results } \\
\text { in increase of porosity and permeability, } \\
\text { cracking and spalling. IWL, Examination } \\
\text { Category L-A, requires periodic examination of } \\
\text { accessible concrete surfaces and } \\
\S 50.55 a(b)(2) \text { (ix) (E) requires an evaluation of } \\
\text { inaccessible areas when conditions exist in } \\
\text { accessible areas that could indicate the } \\
\text { presence of or result in degradation to such } \\
\text { inaccessible areas. Regardless of whether the } \\
\text { above conditions are met, potential aggressive } \\
\text { chemical attack would be detected by IWL and } \\
\text { \$50.55a(b) (2) (ix) (E). However, the management } \\
\text { of potential aggressive chemical attack of } \\
\text { inaccessible areas when conditions in } \\
\text { accessible areas may not indicate the presence } \\
\text { of or result in degradation to such } \\
\text { inaccessible areas needs to be evaluated. }\end{array}$ \\
\hline
\end{tabular}




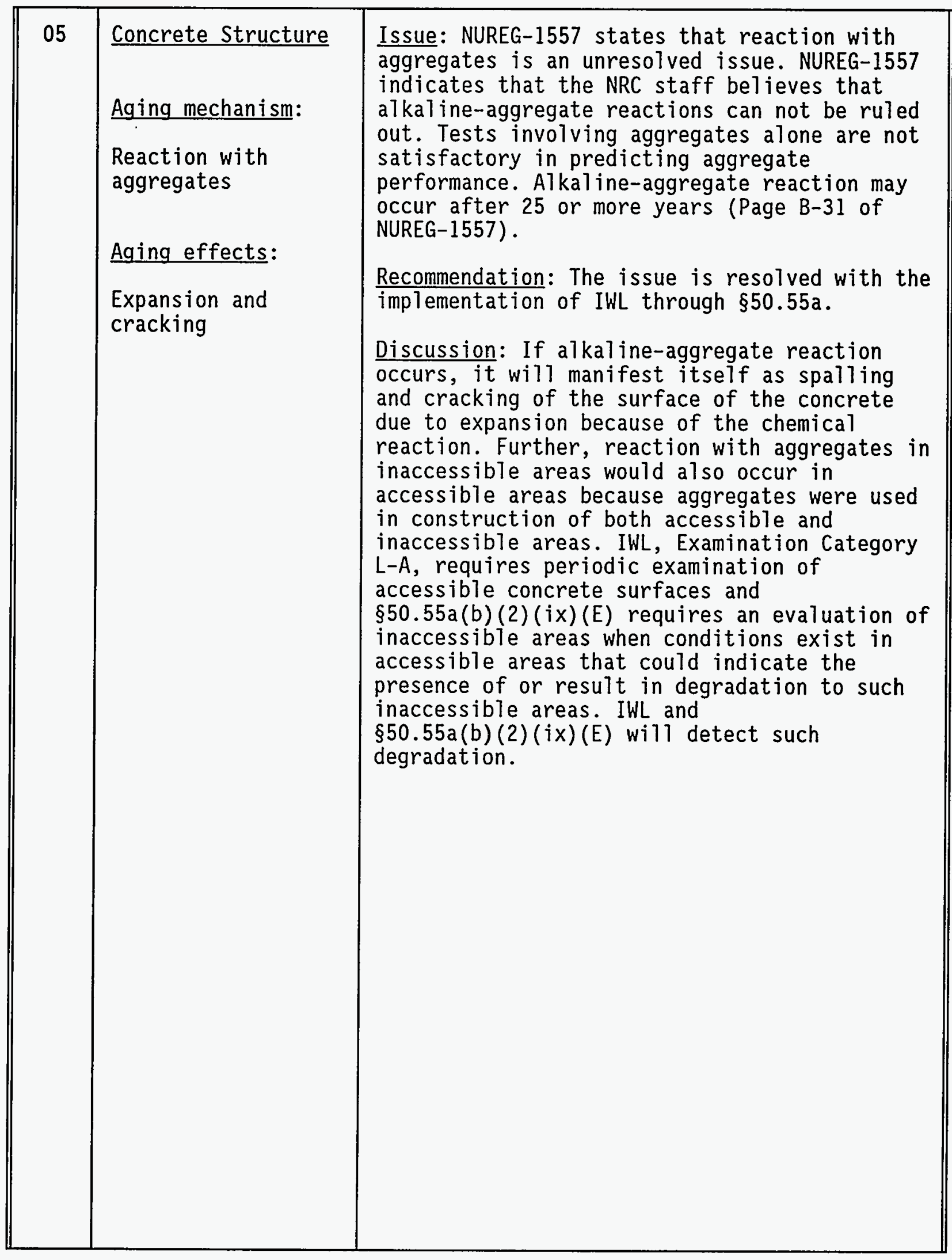




\begin{tabular}{|c|c|c|}
\hline 06 & $\begin{array}{l}\text { Concrete Structure } \\
\text { Aging mechanism: } \\
\text { Elevated } \\
\text { temperature } \\
\text { Aging effects: } \\
\text { Loss of strength \& } \\
\text { modulus }\end{array}$ & $\begin{array}{l}\text { Issue: NUREG-1557 states that elevated } \\
\text { temperature is non-significant for concrete } \\
\text { structures if it meets the following } \\
\text { conditions: concrete containment structures be } \\
\text { maintained at operating temperatures }<66^{\circ} \mathrm{C} \\
\left(150^{\circ} \mathrm{F}\right) \text { and local area temperatures }<93^{\circ} \mathrm{C} \\
\left(200^{\circ} \mathrm{F}\right) \text {; or for concrete structures that } \\
\text { experience temperatures greater than the above } \\
\text { specified limits, a plant specific } \\
\text { justification should be provided (Page B-32 of } \\
\text { NUREG-1557). } \\
\text { Recommendation: For concrete containment } \\
\text { structures that experience temperatures } \\
\text { greater than the above specified limits, a } \\
\text { plant specific evaluation is needed. } \\
\text { Discussion: Elevated temperature results in } \\
\text { loss of concrete strength and modulus which } \\
\text { may not be detected by the implementation of } \\
\text { IWL and } \$ 50.55 a \text { modification until the aging } \\
\text { effects are so severe as to result in cracking } \\
\text { and spalling. Thus, for concrete structures } \\
\text { that experience temperatures greater than the } \\
\text { above specified limits, a plant specific } \\
\text { justification should be provided. }\end{array}$ \\
\hline 07 & $\begin{array}{l}\text { Concrete Structure } \\
\text { Aging mechanism: } \\
\text { Irradiation of } \\
\text { concrete } \\
\text { Aging effects: } \\
\text { Loss of strength \& } \\
\text { modulus }\end{array}$ & $\begin{array}{l}\text { Issue: NUREG-1557 states that irradiation of } \\
\text { concrete is non-significant for containment } \\
\text { concrete structures (Page B-34 of NUREG-1557). } \\
\text { Recommendation: The issue is non-significant. } \\
\text { Discussion: The neutron fluence levels and } \\
\text { maximum integrated gamma doses experienced by } \\
\text { containment concrete during the license } \\
\text { renewal term is not expected to exceed the } \\
\text { level at which measurable degradation of } \\
\text { concrete strength properties occurs }\left(10^{19} \mathrm{n} / \mathrm{cm}^{2}\right. \\
\& 10^{10} \text { rads, respectively). Thus the issue is } \\
\text { non-significant. }\end{array}$ \\
\hline
\end{tabular}




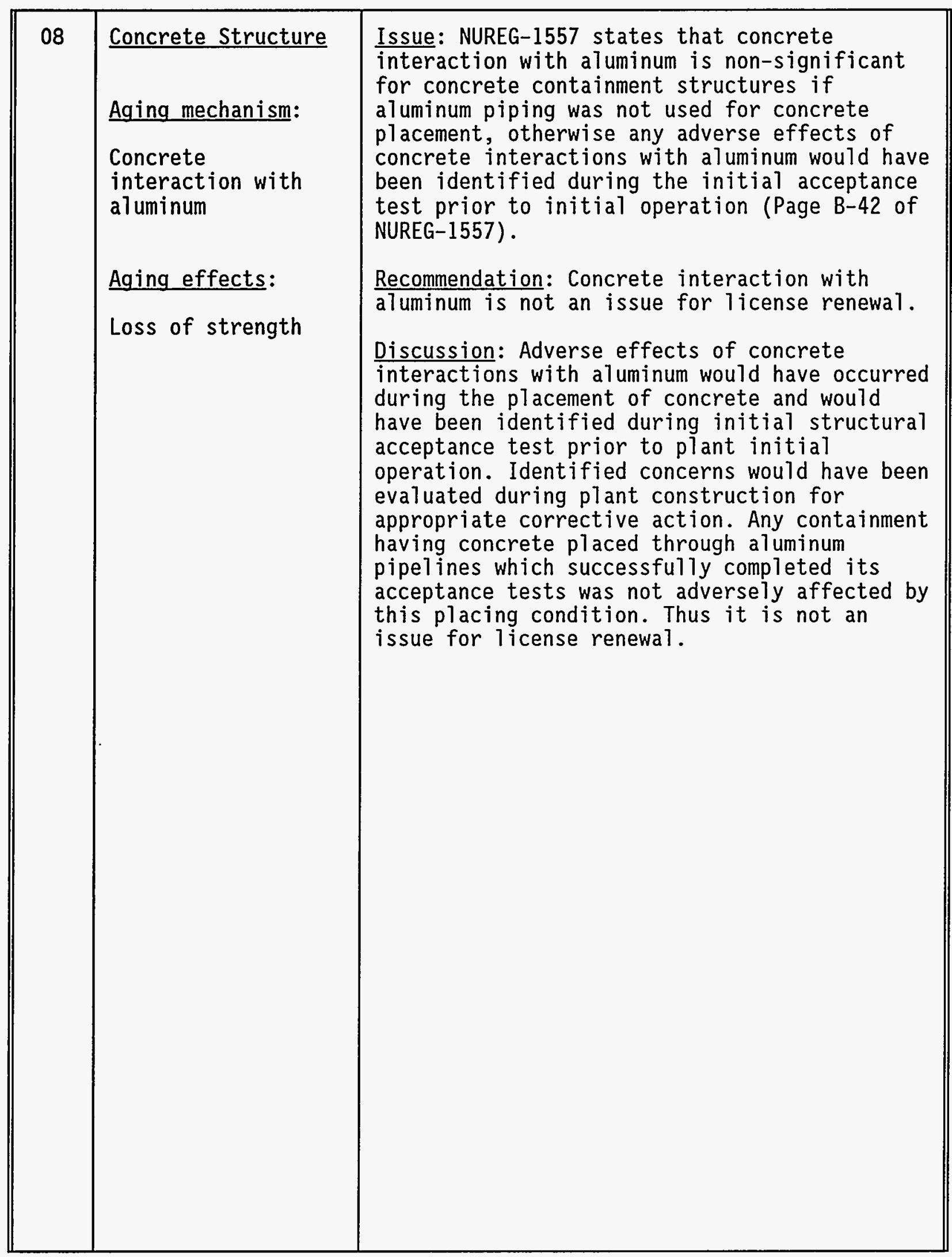




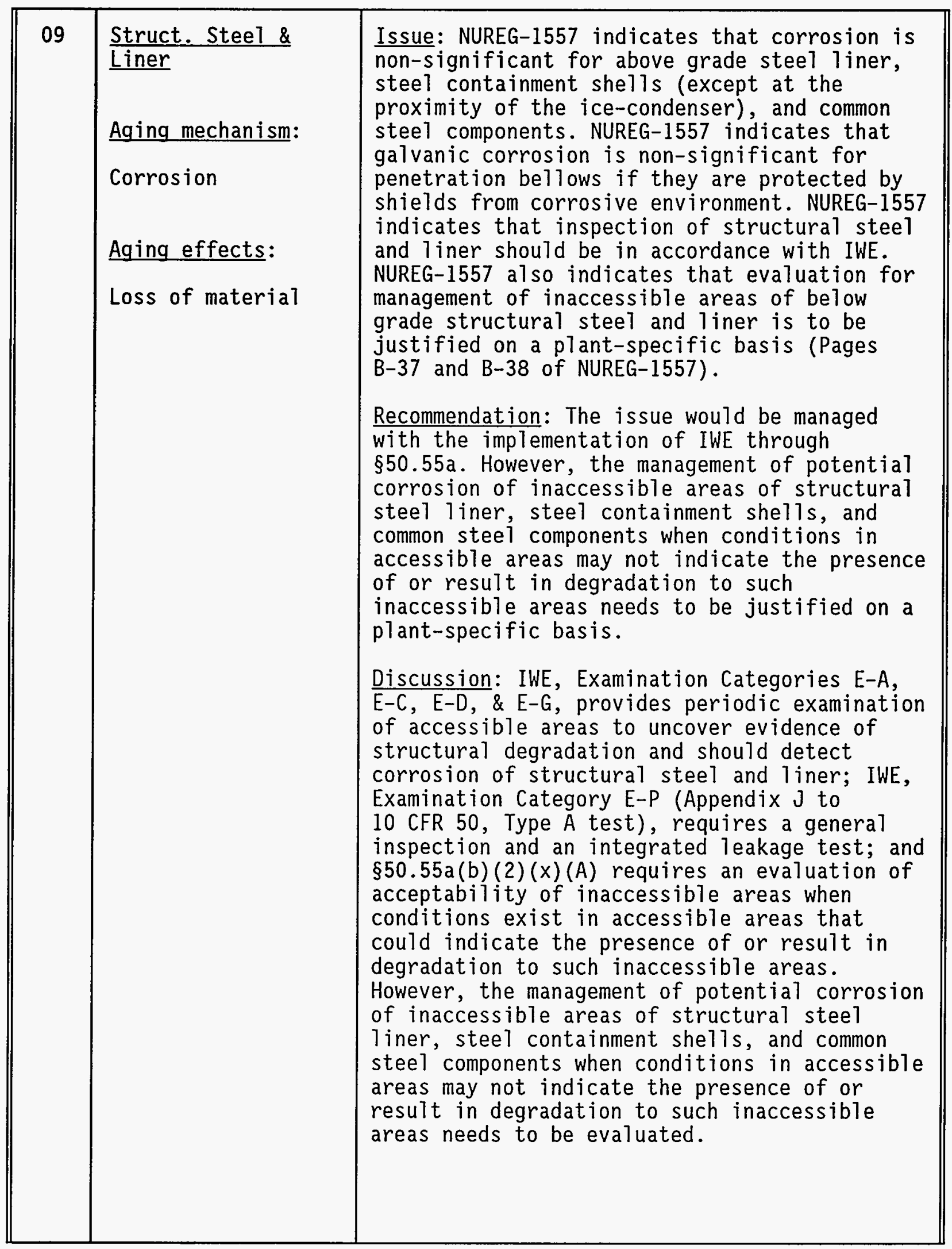




\begin{tabular}{|c|c|c|}
\hline 10 & $\begin{array}{l}\text { Struct. Steel \& } \\
\text { Aginer } \\
\text { Elevated } \\
\text { temperature } \\
\text { Aging effects: } \\
\text { Loss of strength \& } \\
\text { moduius }\end{array}$ & $\begin{array}{l}\text { Issue: NUREG-1557 states that elevated } \\
\text { temperature is non-significant for containment } \\
\text { structural steel liner, steel containment } \\
\text { shells, and common steel components such as } \\
\text { penetration bellows/sleeves, personnel } \\
\text { airlock, equipment hatches (Page B-33 of } \\
\text { NUREG-1557). } \\
\text { Recommendation: The issue is non-significant. } \\
\text { Discussion: Operating temperatures within PWR } \\
\text { containment structures are } 49-66^{\circ} \mathrm{C} \text { (120-150 } \\
\text { which are well below the } 316^{\circ} \mathrm{C}\left(600^{\circ} \mathrm{F} \text { ) level }\right. \\
\text { at which the structural integrity of } \\
\text { rebar/concrete combination begins to be } \\
\text { significantly affected. Thus the issue is non- } \\
\text { significant. }\end{array}$ \\
\hline 11 & $\begin{array}{l}\text { Struct. Steel \& } \\
\text { Liner } \\
\text { Aging mechanism: } \\
\text { Irradiation of } \\
\text { steel } \\
\text { Aging effects: } \\
\text { Loss of fracture } \\
\text { toughness }\end{array}$ & $\begin{array}{l}\text { Issue: NUREG-1557 states that irradiation of } \\
\text { steel is non-significant for containment } \\
\text { structural steel liner, containment shelis, } \\
\text { and common steel components (Page B-35 of } \\
\text { NUREG-1557). } \\
\text { Recommendation: The issue is non-significant. } \\
\text { Discussion: The cumulative radiation exposure } \\
\text { experienced by concrete containment liners or } \\
\text { free-standing steel containment shells } \\
\text { throughout the license renewal term is } \\
\text { expected to be far below the level of } \\
2 \times 10^{17} \text { n/ } \mathrm{cm}^{2} \text { (>1 MeV) which could cause a change } \\
\text { in mechanical or physical properties. Thus the } \\
\text { issue is non-significant. }\end{array}$ \\
\hline
\end{tabular}




\begin{tabular}{|c|c|c|}
\hline 12 & $\begin{array}{l}\frac{\text { Struct. Stee } \&}{\text { Liner }} \\
\text { Aging mechanism: } \\
\text { Stress corrosion } \\
\text { cracking (SCC) } \\
\text { Aging effects: } \\
\text { Crack initiation \& } \\
\text { growth }\end{array}$ & $\begin{array}{l}\text { Issue: NUREG-1557 indicates that SCC is non- } \\
\text { significant for concrete containment steel } \\
\text { liner, free-standing steel containment shells, } \\
\text { and common steel components in the containment } \\
\text { environment unless dissimilar metal is used, } \\
\text { and in the case of SS bellows assemblies for } \\
\text { CS vent lines or pipe sleeves if the materials } \\
\text { are protected by shields from corrosive } \\
\text { environment (Page B-37 of NUREG-1557). } \\
\text { Recommendation: This issue would be managed by } \\
\text { Examination Categories E-B \& E-F of Subsection } \\
\text { IWE and Appendix J to lo CFR 50. In addition, } \\
\text { an augmented VT-1 visual examination of } \\
\text { bellows bodies should be performed using } \\
\text { enhanced techniques qualified for detecting } \\
\text { stress corrosion cracking in bellows bodies. } \\
\text { Discussion: IWE, Examination Category E-F, } \\
\text { provides periodic surface examination of } \\
\text { pressure retaining dissimilar metal welds for } \\
\text { dissimilar metals and could detect scC. IWE, } \\
\text { Examination Category E-B, provides periodic } \\
\text { visual examination of pressure retaining welds } \\
\text { for containment penetrations. Also, any } \\
\text { leakage associated with the containment shell } \\
\text { or steel liner due to through-wall cracks } \\
\text { resulting from SCC would be detected by } \\
\text { periodic Appendix J leak rate test \& remains } \\
\text { within the Iimits of plant specifications or } \\
\text { Subsection IWE. Although §50.55a indicates } \\
\text { that Examination Categories E-B \& E-F are } \\
\text { optional during the current term of operation, } \\
\text { these examinations should be performed for } \\
\text { license renewal to demonstrate that no SCC has } \\
\text { been initiated. In addition, since occurrences } \\
\text { of transgranular stress corrosion cracking } \\
\text { have been identified in operating plants on } \\
\text { stainless steel bellows [Reference } 15 \text { ], an } \\
\text { augmented examination on the surface areas of } \\
\text { bellows bodies should be performed so that } \\
\text { cracking would be detected. }\end{array}$ \\
\hline
\end{tabular}




\begin{tabular}{|c|c|c|}
\hline 13 & $\begin{array}{l}\text { Reinforcing Steel } \\
\text { (Rebar) } \\
\text { Aging mechanism: } \\
\text { Corrosion of } \\
\text { embedded steel } \\
\text { Aging effects: } \\
\text { Loss of bond \& loss } \\
\text { of material }\end{array}$ & $\begin{array}{l}\text { Issue: NUREG-1557 states that corrosion of } \\
\text { embedded steel is non-significant for concrete } \\
\text { structures above grade if not exposed to } \\
\text { aggressive environment, pH<1l.5 or chlorides } \\
\text { >500 ppm; or if exposed to aggressive } \\
\text { environment, concrete has relatively high } \\
\text { strength [27.6 MPa (4 ksi)], low water-to- } \\
\text { cement ratio (0.35-0.45), adequate air } \\
\text { entrainment ( } 3-6 \% \text { ), low permeability, and } \\
\text { designed in accordance with ACI } 318 \text { or ASME } \\
\text { Section III, Division } 2 \text {. NUREG-1557 also } \\
\text { indicates corrosion of embedded steel for } \\
\text { concrete structures below grade exposed to } \\
\text { aggressive ground water (pH <5.5, chloride } \\
\text { >500 ppm, \& sulfate >1500 ppm) should be } \\
\text { examined in accordance with IWL and management } \\
\text { of inaccessible areas should be justified on a } \\
\text { case by case basis. Also the NRC staff } \\
\text { considers that potential degradation due to } \\
\text { chloride corrosion (e.g., ground water } \\
\text { chemical attack) of PWR containments should be } \\
\text { addressed (Page B-36 of NUREG-1557). } \\
\text { Recommendation: The issue would be managed } \\
\text { with the implementation of IWL through } \\
\text { \$50.55a. However, the management of potential } \\
\text { corrosion of inaccessible areas of embedded } \\
\text { steel when conditions in accessible areas may } \\
\text { not indicate the presence of or result in } \\
\text { degradation to such inaccessible areas needs } \\
\text { to be justified on a plant-specific basis. } \\
\text { Discussion: IWL, Examination Category L-A, } \\
\text { requires periodic examination of accessible } \\
\text { concrete surfaces and } 550.55 a \text { (b) ( } 2 \text { ) (ix) (E) } \\
\text { requires an evaluation of inaccessible areas } \\
\text { when conditions exist in accessible areas that } \\
\text { could indicate the presence of or result in } \\
\text { degradation to such inaccessible areas. } \\
\text { Corrosion of embedded steel results in } \\
\text { cracking and spalling of concrete and would be } \\
\text { detected by inspections, regardless of whether } \\
\text { the above conditions are met. However, the } \\
\text { management of potential corrosion of } \\
\text { inaccessible areas of embedded steel, when } \\
\text { conditions in accessible areas may not } \\
\text { indicate the presence of or result in } \\
\text { degradation to such inaccessible areas needs } \\
\text { to be evaluated. This would also address the } \\
\text { staff's concern on chloride corrosion. }\end{array}$ \\
\hline
\end{tabular}




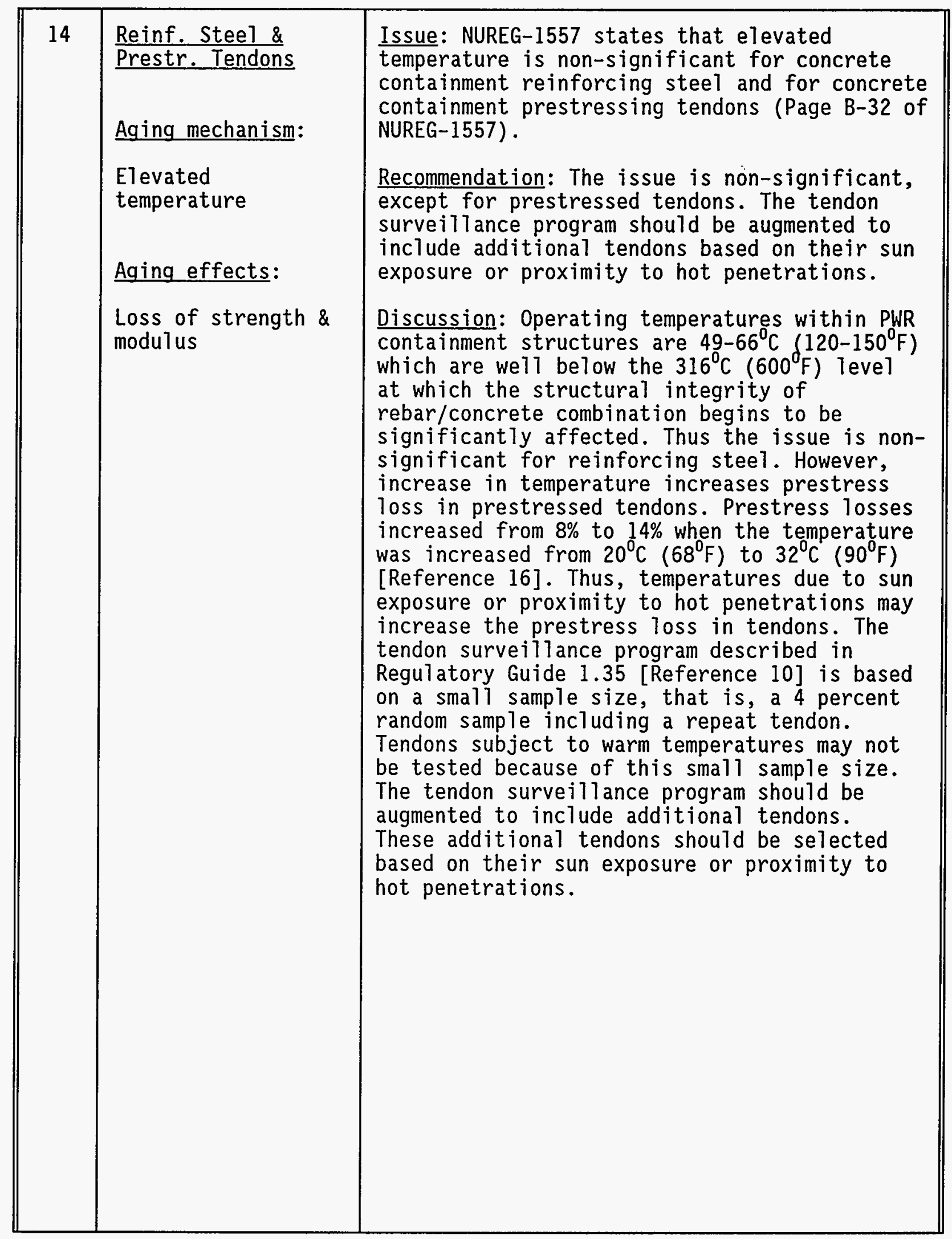




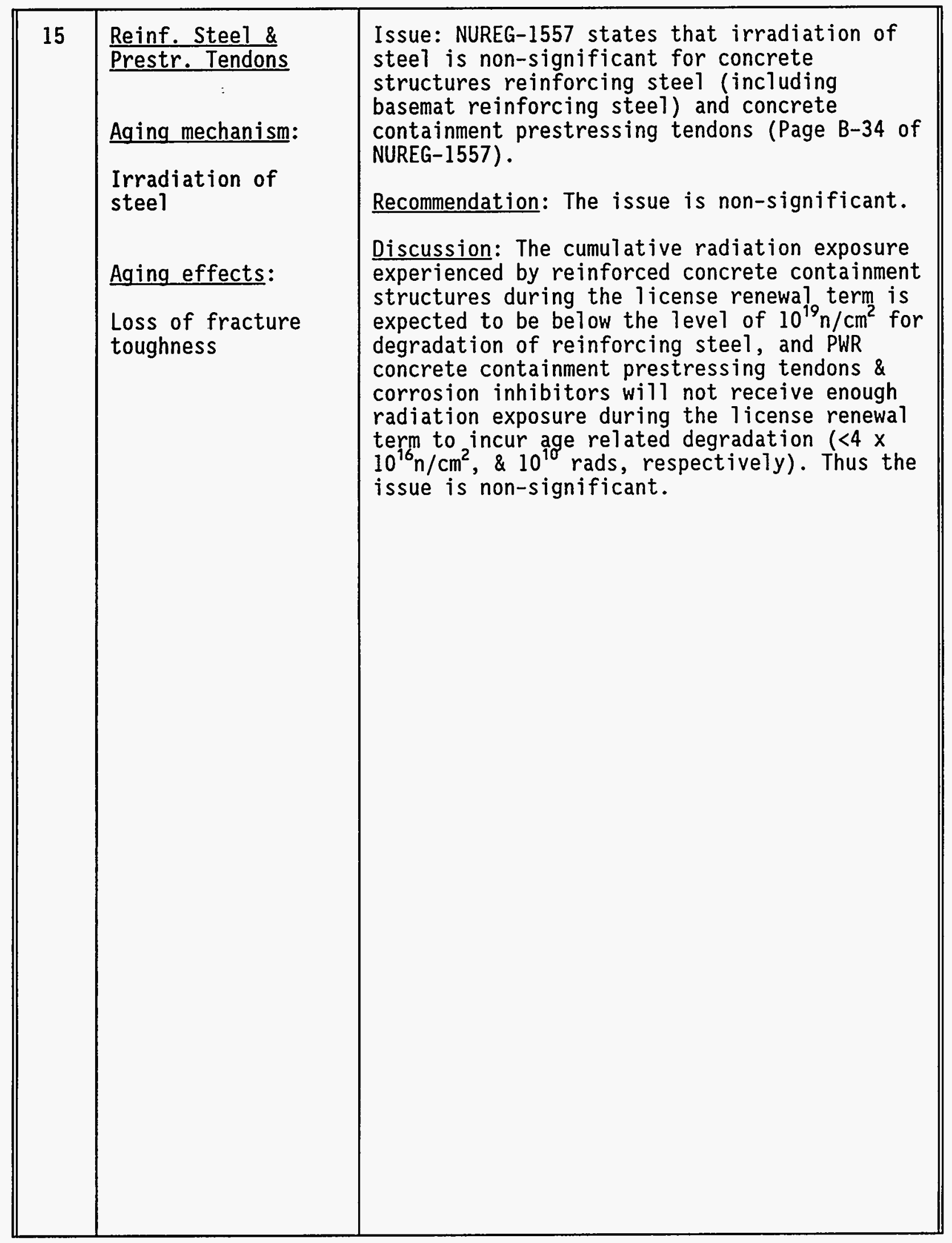




\begin{tabular}{|c|c|c|}
\hline 16 & $\begin{array}{l}\frac{\text { Containment }}{\frac{\text { Structures \& }}{\text { Components }}} \\
\text { Aging mechanism: } \\
\text { Fatigue } \\
\text { Aging effects: } \\
\begin{array}{l}\text { Cumulative fatigue } \\
\text { damage }\end{array}\end{array}$ & $\begin{array}{l}\text { Issue: NUREG-1557 states that fatigue is non- } \\
\text { significant for containment structures and its } \\
\text { components, except for the penetration sleeves } \\
\text { and bellows. NUREG-1557 also indicates that } \\
\text { fatigue is an unresolved issue for concrete } \\
\text { containment penetration sleeves and steel } \\
\text { containment penetration bellows and fatigue } \\
\text { damage may not be detectable by a leak rate } \\
\text { test (Pages B-40 \& B-4l of NUREG-1557). } \\
\text { Recommendation: Fatigue is non-significant for } \\
\text { containment structures and its components } \\
\text { except for the penetration sleeves and } \\
\text { bellows. Fatigue of containment penetration } \\
\text { sleeves and penetration bellows is a "time- } \\
\text { limited aging analysis" and must be evaluated } \\
\text { in accordance with the license renewal rule, } \\
\text { I0 CFR } 54.21 \text { (c). } \\
\text { Discussion: Fatigue is non-significant for } \\
\text { containment concrete, reinforcing steel, } \\
\text { prestressing system components, steel liners, } \\
\text { and free-standing steel containments, because } \\
\text { they are designed to have good fatigue } \\
\text { strength properties (105 cycles) of below } \\
\text { yield load in accordance with ASME Section } \\
\text { III, Division } 2 \text {, or ACI } 318 \text {, and ACI } 215 R-74 \\
\text { codes. } \\
\text { Containment penetration sleeves and } \\
\text { penetration bellows are designed to Section } \\
\text { III of the ASME Code which requires a fatigue } \\
\text { analysis based on an assumed number of cycles. } \\
\text { This fatigue analysis is a "time-limited aging } \\
\text { analysis" and must be evaluated in accordance } \\
\text { with license renewal rule } \$ 54.21 \text { (c) to ensure } \\
\text { that the effects of aging on the intended } \\
\text { functions will be adequately managed for the } \\
\text { period of extended operation. }\end{array}$ \\
\hline
\end{tabular}




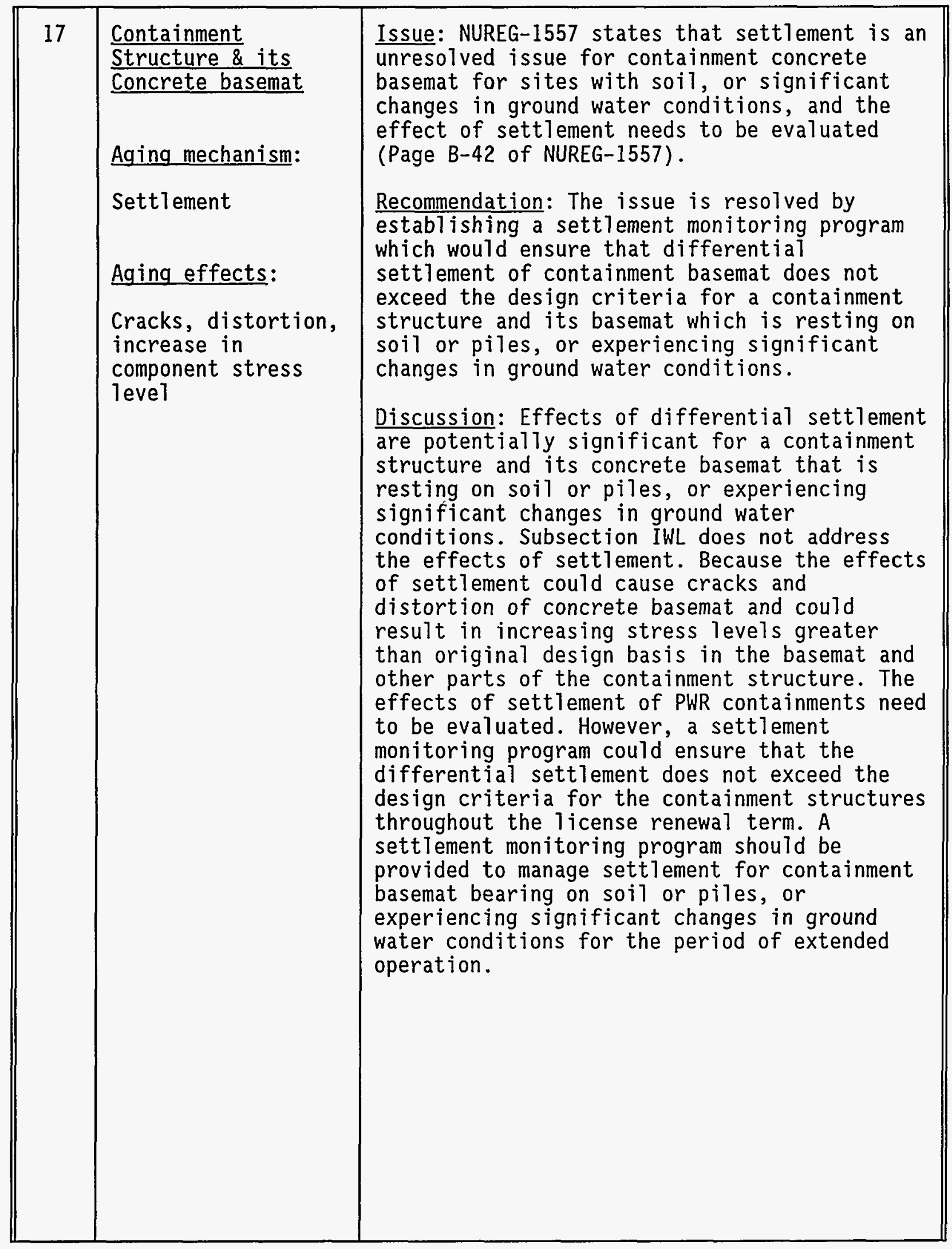




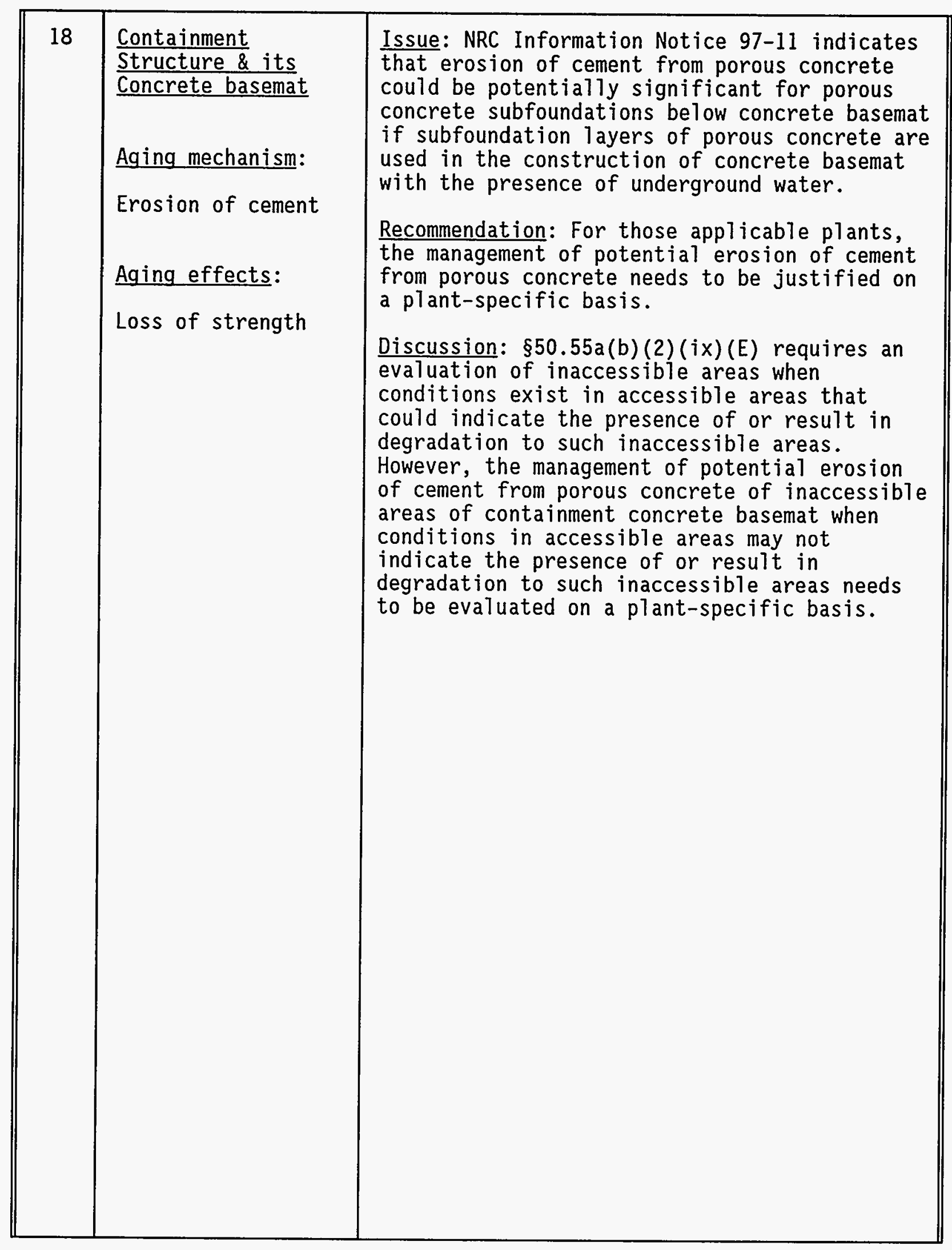




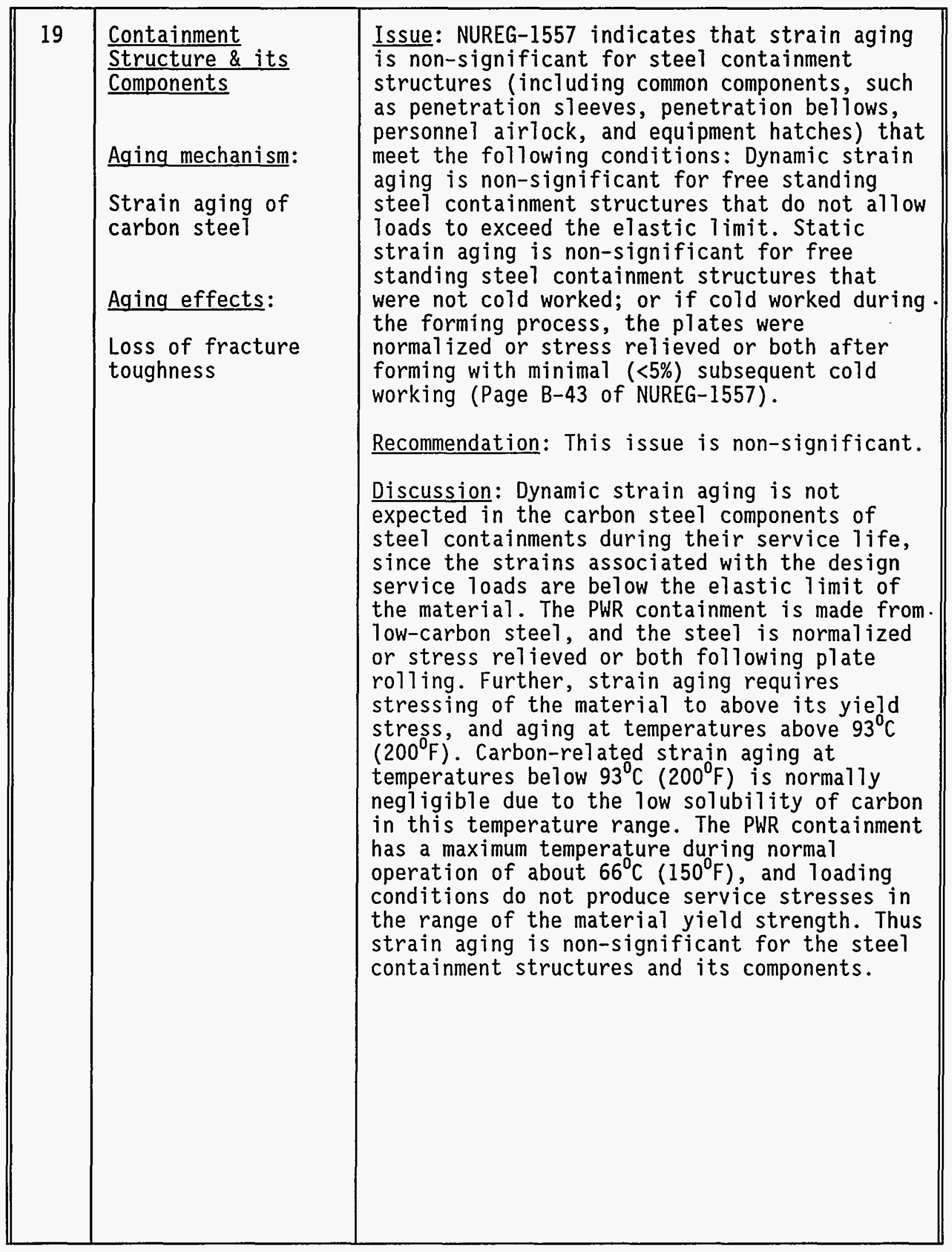




\begin{tabular}{|c|c|c|}
\hline 20 & $\begin{array}{l}\text { Conc. Containment } \\
\text { Prestr. Tendons } \\
\text { Aging mechanism: } \\
\text { Stress relaxation } \\
\text { of prestressing } \\
\text { wire, shrinkage } \\
\text { creep, anchorage } \\
\text { seating losses, and } \\
\text { tendon friction } \\
\text { Aging effects: } \\
\text { Loss of prestress }\end{array}$ & 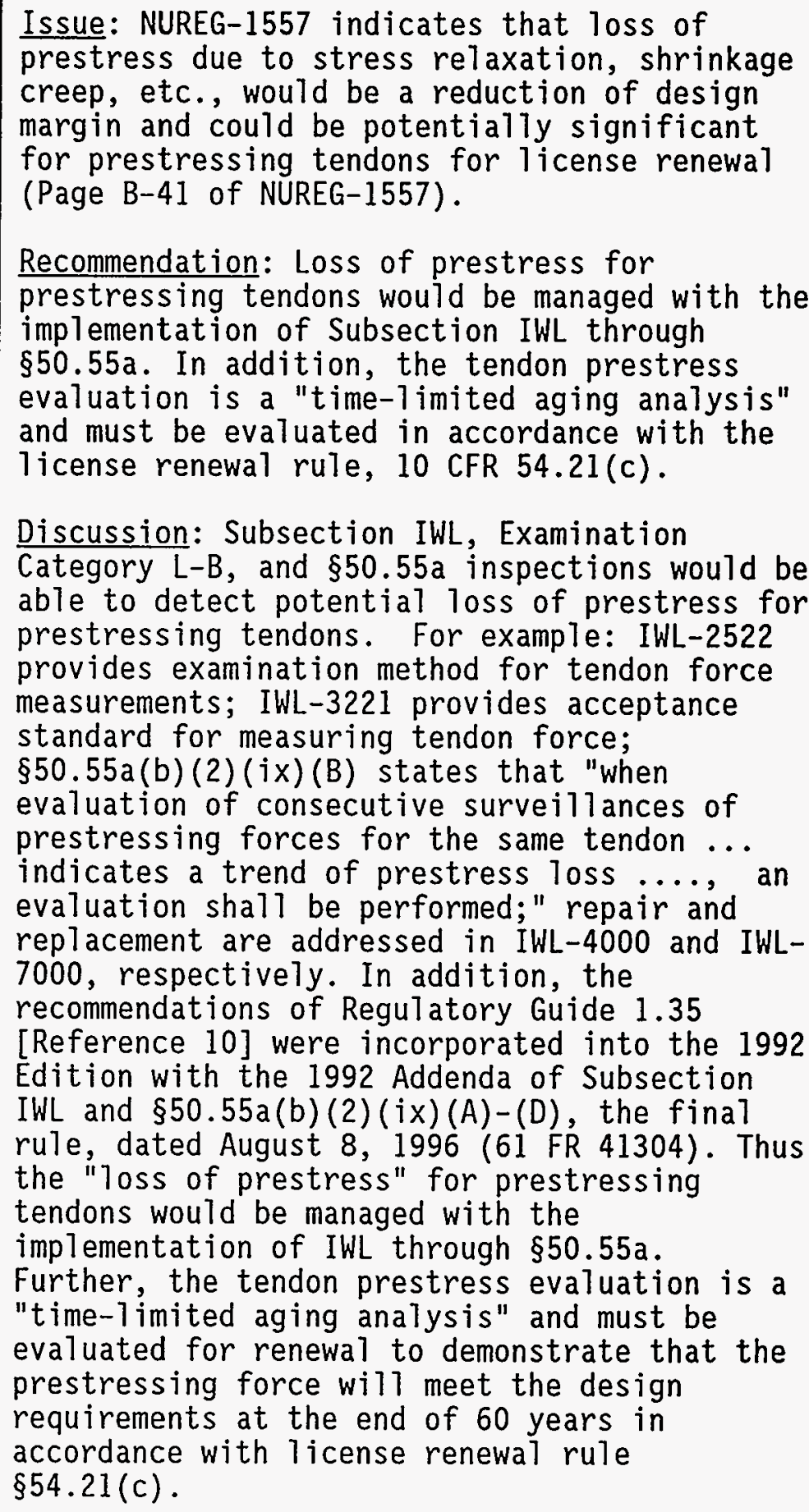 \\
\hline
\end{tabular}




\begin{tabular}{|c|c|c|}
\hline 21 & $\begin{array}{l}\text { Conc. Containment } \\
\text { Prestr. Tendons } \\
\text { Aging mechanism: } \\
\text { Corrosion of } \\
\text { tendons } \\
\text { Aging effects: } \\
\text { Loss of material }\end{array}$ & 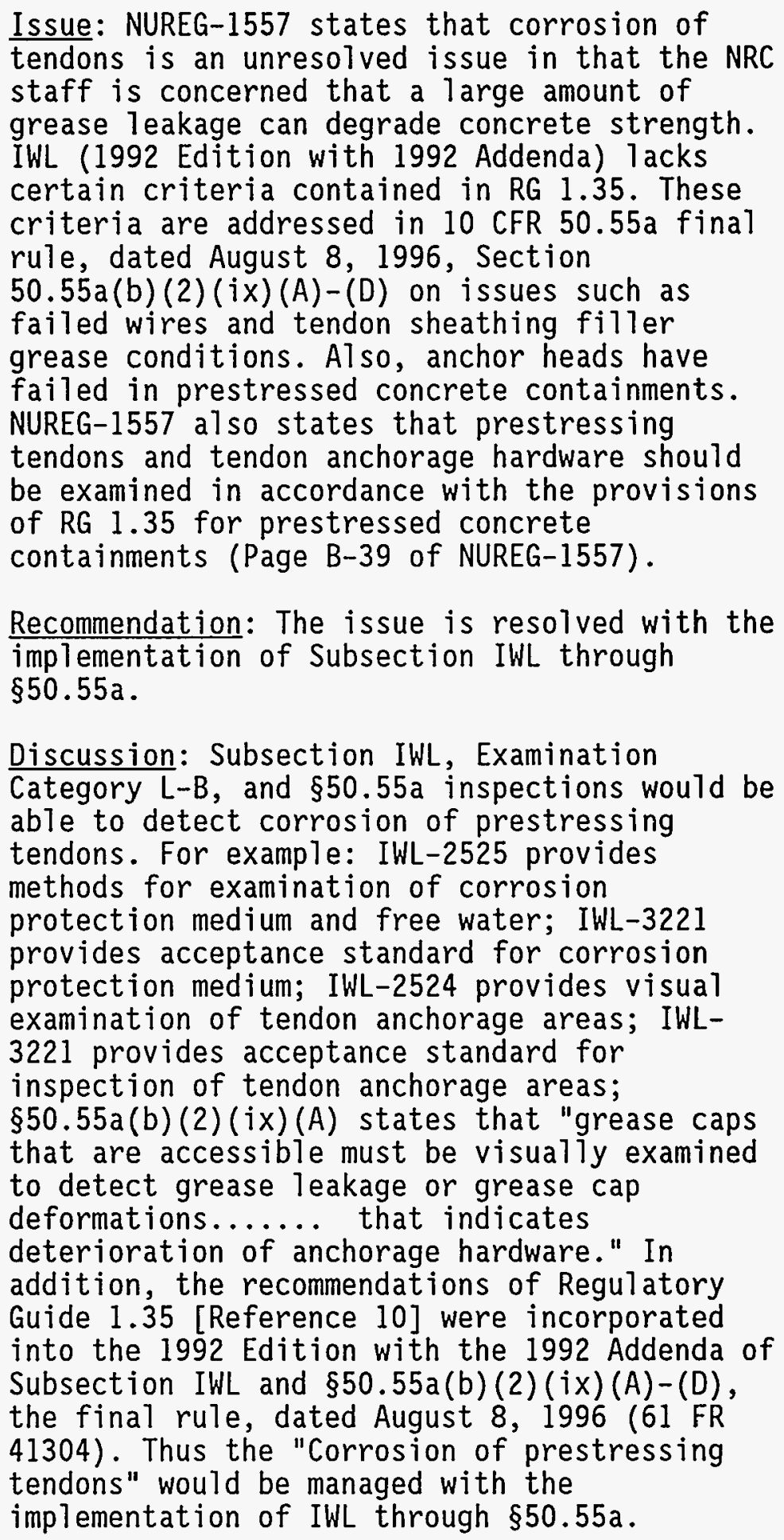 \\
\hline
\end{tabular}




\begin{tabular}{|c|c|c|}
\hline 22 & $\begin{array}{l}\frac{\text { Containment }}{\text { Pressure Retaining }} \\
\underline{\text { Components }} \\
\text { Aging mechanism: } \\
\text { Mechanical Wear } \\
\text { Aging effects: } \\
\text { Fretting, Lockup }\end{array}$ & $\begin{array}{l}\text { Issue: NUREG-1557 does not address mechanical } \\
\text { wear for PWR containments. However, } \\
\text { mechanical wear could be potentially } \\
\text { significant for components that are subject to } \\
\text { relative sliding or rotating motion and that } \\
\text { are susceptible to fretting and/or lockup. } \\
\text { Recommendation: Mechanical wear for PWR } \\
\text { containment pressure retaining components } \\
\text { would be managed with the implementation of } \\
\text { Subsection IWE (Examination Categories E-D, E- } \\
\text { G, and E-P). } \\
\text { Discussion: NUREG-1557 addresses mechanical } \\
\text { wear issue only for BWR containments. However, } \\
\text { mechanical wear should also be addressed for } \\
\text { PWR containments. Inspection and mitigation of } \\
\text { mechanical wear conducted in accordance with } \\
\text { the provisions of Subsections IWE \& IWF, as } \\
\text { applicable, would ensure that the integrity of } \\
\text { containment pressure retaining components and } \\
\text { their supports is maintained throughout the } \\
\text { license renewal term. IWE, Examination } \\
\text { Categories E-D \& E-G, provides periodic } \\
\text { examinations for the pressure retaining } \\
\text { components (including airlocks, and equipment } \\
\text { hatches). IWE, Examination Category E-P } \\
\text { (Appendix J to Part 50, Type B test), would } \\
\text { detect local leaks for those components. Thus } \\
\text { any potential mechanical wear degradation } \\
\text { would be detected by the implementation of IWE } \\
\text { for those pressure retaining components. } \\
\text { (There are no PWR containment pressure } \\
\text { retaining component supports listed in } \\
\text { Appendix B of this report and therefore, } \\
\text { Subsection IWF is not applicable.) }\end{array}$ \\
\hline
\end{tabular}

* Evaluation is based on:

(1) the 1992 Edition with the 1992 Addenda of Subsections IWE and IWL of Section XI of the ASME Code;

(2) the 1989 Edition of Section XI of the ASME Code including Appendix VII, "Qualification of Nondestructive Examination Personnel for UTtrasonic Examination," and Appendix VIII (1989 Addenda), "Performance Demonstration for Ultrasonic Examination Systems;"

(3) the final rule on 10 CFR 50.55a, Codes and Standards, dated August 8, 1996 (61 FR 41303); and

(4) NUREG-1557, "Summary of Technical Information and Agreements from Nuclear Management and Resources Council Industry Reports Addressing License Renewa1," dated October 1996. 
TABLE 2. AGING MANAGEMENT OF BWR CONTAINMENTS FOR LICENSE RENEWAL.

\begin{tabular}{|c|c|c|}
\hline Item & $\begin{array}{l}\text { Component, Aging } \\
\text { Mechanism \& Aging } \\
\text { Effects }\end{array}$ & Issue and Evaluation" \\
\hline 01 & $\begin{array}{l}\frac{\text { Concrete \& Steel }}{\text { Containment }} \\
\text { Aging mechanism: } \\
\text { Not applicable. } \\
\text { Aging effects: } \\
\text { General }\end{array}$ & $\begin{array}{l}\text { Issue: A "one-time inspection for license } \\
\text { renewal." NUREG-1557 states that one time } \\
\text { inspection is an unresolved issue regarding } \\
\text { staff request for inspection of concrete } \\
\text { containment \& steel containment to assess the } \\
\text { current condition of containment and to } \\
\text { provide a baseline information for any future } \\
\text { inspections (Page B-28 of NUREG-1557). } \\
\text { Recommendation: The issue is resolved with the } \\
\text { implementation of IWE/IWL through \$50.55a. } \\
\text { However, specific-recommendations for } \\
\text { applicable aging effects are addressed } \\
\text { hereinafter in this table. } \\
\text { Discussion: Subsections IWE and IWL require } \\
\text { periodic inspection of the containment in } \\
\text { accessible areas. These inspections would } \\
\text { periodically assess the condition of the } \\
\text { containment and each inspection would provide } \\
\text { a documented basel ine for subsequent } \\
\text { inspections. Furthermore, \$50.55a(b) (2) (ix) (E) } \\
\text { and (b) (2) ( } x \text { ) (A) require an evaluation of } \\
\text { inaccessible areas when conditions exist in } \\
\text { accessible areas that could indicate the } \\
\text { presence of or result in degradation to such } \\
\text { inaccessible areas. } \\
\text { However, the management of potential aging } \\
\text { effects of inaccessible areas, when conditions } \\
\text { in accessible areas may not indicate the } \\
\text { presence of or result in degradation to such } \\
\text { inaccessible areas, is addressed individually } \\
\text { for each applicable aging effect ( } i \text {.e., Items } \\
\text { l, } 3 \text {, } 4 \text {, and } 13 \text { of this table). Conditions } \\
\text { for such inaccessible areas should be } \\
\text { evaluated for } 1 \text { icense renewal. A program for a } \\
\text { one-time inspection may be proposed. }\end{array}$ \\
\hline
\end{tabular}




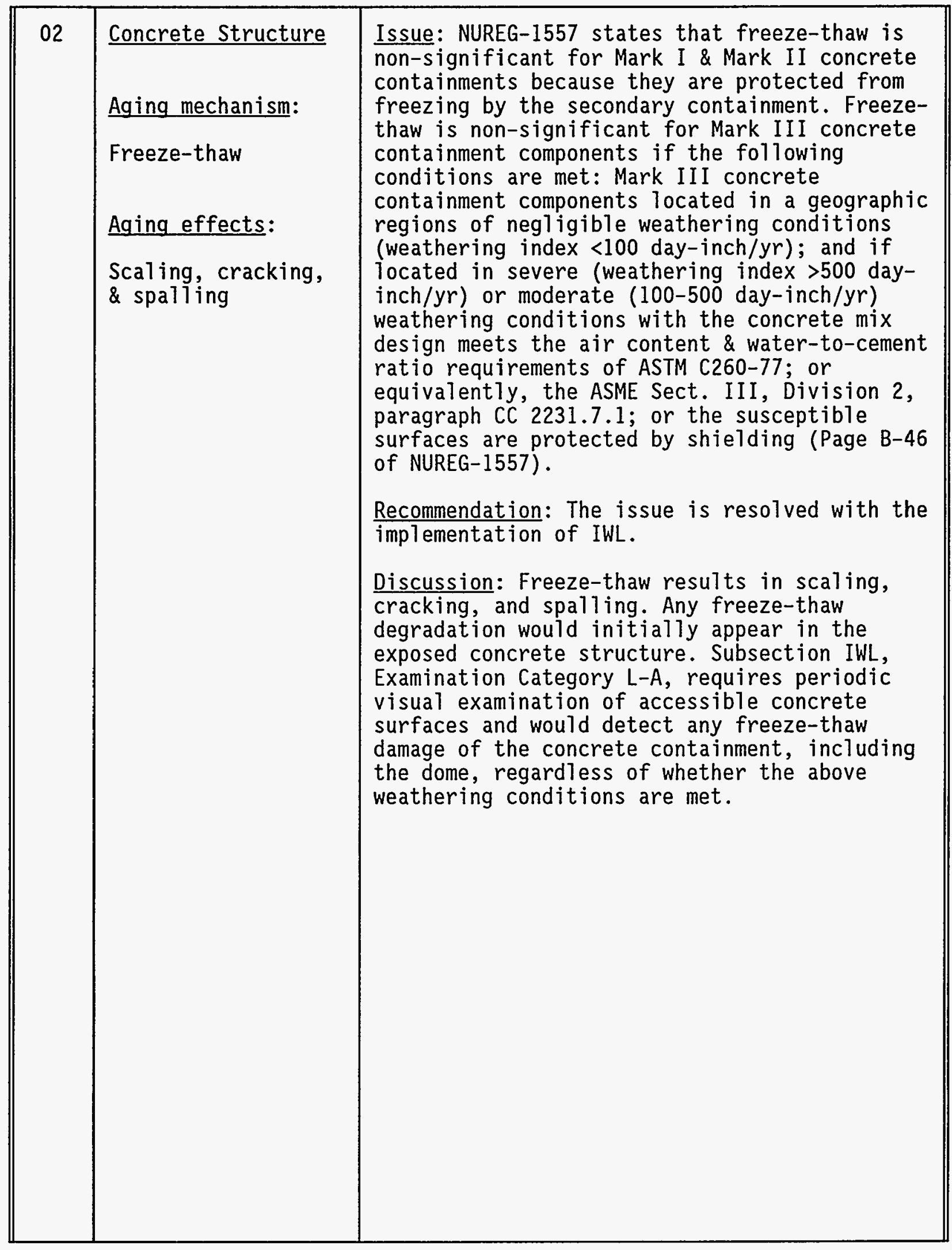




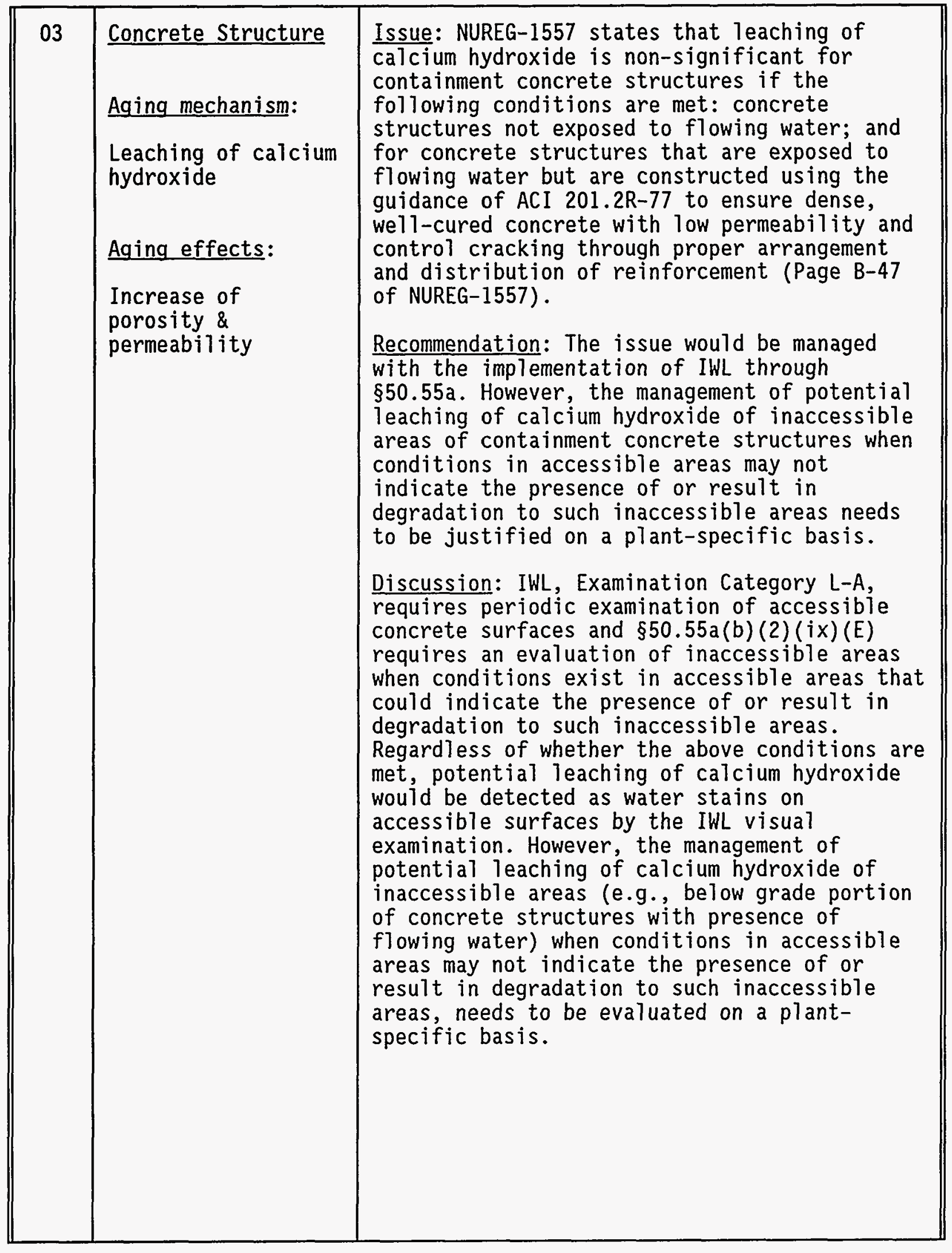




\begin{tabular}{|c|c|c|}
\hline 04 & $\begin{array}{l}\text { Concrete Structure } \\
\text { Aging mechanism: } \\
\begin{array}{l}\text { Aggressive chemical } \\
\text { attack }\end{array} \\
\text { Aging effects: } \\
\text { Increase of } \\
\text { porosity and } \\
\text { permeability, } \\
\text { cracking, and } \\
\text { spalling }\end{array}$ & $\begin{array}{l}\text { Issue: NUREG-1557 states that aggressive } \\
\text { chemical attack is non-significant for above } \\
\text { grade containment concrete structures because } \\
\text { they are not exposed to ground water. } \\
\text { Aggressive chemical attack is non-significant } \\
\text { for below grade containment concrete } \\
\text { structures if the following conditions are } \\
\text { met: containment concrete is not exposed to } \\
\text { aggressive ground water (pH <5.5, chloride } \\
\text { >500 ppm, \& sulfate >1500 ppm); or if expos\%d } \\
\text { to ground water that exceeds the pH, chloride, } \\
\text { sulfate limits, the exposure is for } \\
\text { intermittent periods only. NUREG-1557 } \\
\text { indicates that inspection of containment } \\
\text { concrete structure should be in accordance } \\
\text { with IWL. NUREG-1557 states that evaluation } \\
\text { for management of inaccessible areas of below } \\
\text { grade containment concrete structures is to be } \\
\text { justified on a plant-specific basis (Page B-48 } \\
\text { of NUREG-1557). } \\
\text { Recommendation: The issue would be managed } \\
\text { with the implementation of IWL through } \\
\text { \$50.55a. However, the management of potential } \\
\text { aggressive chemical attack of inaccessible } \\
\text { areas of containment concrete structures when } \\
\text { conditions in accessible areas may not } \\
\text { indicate the presence of or result in } \\
\text { degradation to such inaccessible areas needs } \\
\text { to be justified on a plant-specific basis. } \\
\text { Discussion: Aggressive chemical attack results } \\
\text { in increase of porosity and permeability, } \\
\text { cracking and spalling. IWL, Examination } \\
\text { Category L-A, requires periodic examination of } \\
\text { accessible concrete surfaces and } \\
\text { \$50.55a(b) (2) (ix) (E) requires an evaluation of } \\
\text { inaccessible areas when conditions exist in } \\
\text { accessible areas that could indicate the } \\
\text { presence of or result in degradation to such } \\
\text { inaccessible areas. Regardless of whether the } \\
\text { above conditions are met, potential aggressive } \\
\text { chemical attack would be detected by IWL and } \\
\text { \$50.55a(b) (2) (ix) (E). However, the management } \\
\text { of potential aggressive chemical attack of } \\
\text { inaccessible areas when conditions in } \\
\text { accessible areas may not indicate the presence } \\
\text { of or result in degradation to such } \\
\text { inaccessible areas needs to be evaluated. } \\
\text { ing }\end{array}$ \\
\hline
\end{tabular}




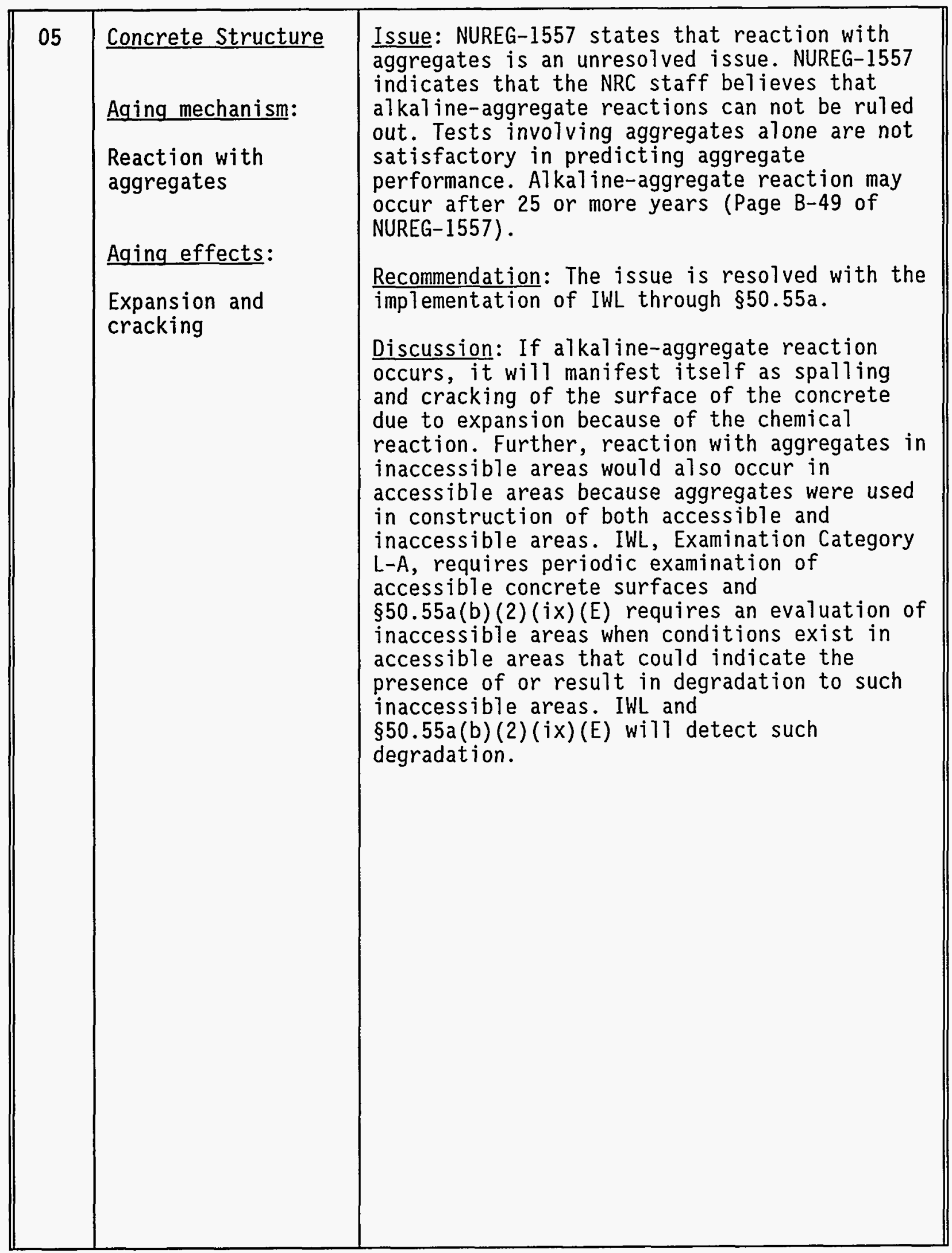




\begin{tabular}{|c|c|c|}
\hline 06 & $\begin{array}{l}\text { Concrete Structure } \\
\text { Aging mechanism: } \\
\text { Elevated } \\
\text { temperature } \\
\text { Aging effects: } \\
\text { Loss of strength \& } \\
\text { modulus }\end{array}$ & $\begin{array}{l}\text { Issue: NUREG-1557 states that elevated } \\
\text { temperature is non-significant for concrete } \\
\text { structures if it meets the following } \\
\text { conditions: concrete containment structures be } \\
\text { maintained at operating temperatures }<66^{\circ} \mathrm{C} \\
\left(150^{\circ} \mathrm{F}\right) \text { and local area temperatures }<93^{\circ} \mathrm{C} \\
\left(200^{\circ} \mathrm{F}\right) \text {; or for concrete structures that } \\
\text { experience temperatures greater than the above } \\
\text { specified limits, a plant specific } \\
\text { justification should be provided (Page B-56 of } \\
\text { NUREG-1557). } \\
\text { Recommendation: For concrete structures that } \\
\text { experience temperatures greater than the above } \\
\text { specified limits, a plant specific evaluation } \\
\text { should be performed. } \\
\text { Discussion: Elevated temperature results in } \\
\text { loss of concrete strength and modulus which } \\
\text { may not be detected by the implementation of } \\
\text { IWL and } 550.55 \text { a modification until the aging } \\
\text { effects are so severe as to result in cracking } \\
\text { and spalling. Thus, for concrete structures } \\
\text { that experience temperatures greater than the } \\
\text { above specified limits, a plant specific } \\
\text { justification should be provided. }\end{array}$ \\
\hline 07 & $\begin{array}{l}\text { Concrete Structure } \\
\text { Aging mechanism: } \\
\text { Irradiation of } \\
\text { concrete } \\
\text { Aging effects: } \\
\text { Loss of strength \& } \\
\text { modulus }\end{array}$ & $\begin{array}{l}\text { Issue: NUREG-1557 states that irradiation of } \\
\text { concrete is non-significant for containment } \\
\text { concrete structures (Page B-57 of NUREG-1557). } \\
\text { Recommendation: The issue is non-significant. } \\
\text { Discussion: The neutron fluence levels and } \\
\text { maximum integrated gamma doses experienced by } \\
\text { containment concrete during the license } \\
\text { renewal term is not expected to exceed the } \\
\text { level at which measurable degradation of } \\
\text { concrete strength properties occurs (10 } \mathrm{n} / \mathrm{cm}^{2} \\
\text { neutron radiation \& } 10^{10} \text { rads gamma radiation, } \\
\text { respectively for concrete). Thus the issue is } \\
\text { non-significant. }\end{array}$ \\
\hline
\end{tabular}




\begin{tabular}{|c|c|c|}
\hline 08 & $\begin{array}{l}\text { Struct. Steel \& } \\
\text { Liner } \\
\text { Aging mechanism: } \\
\text { Atmospheric } \\
\text { corrosion } \\
\text { Aging effects: } \\
\text { Loss of material }\end{array}$ & 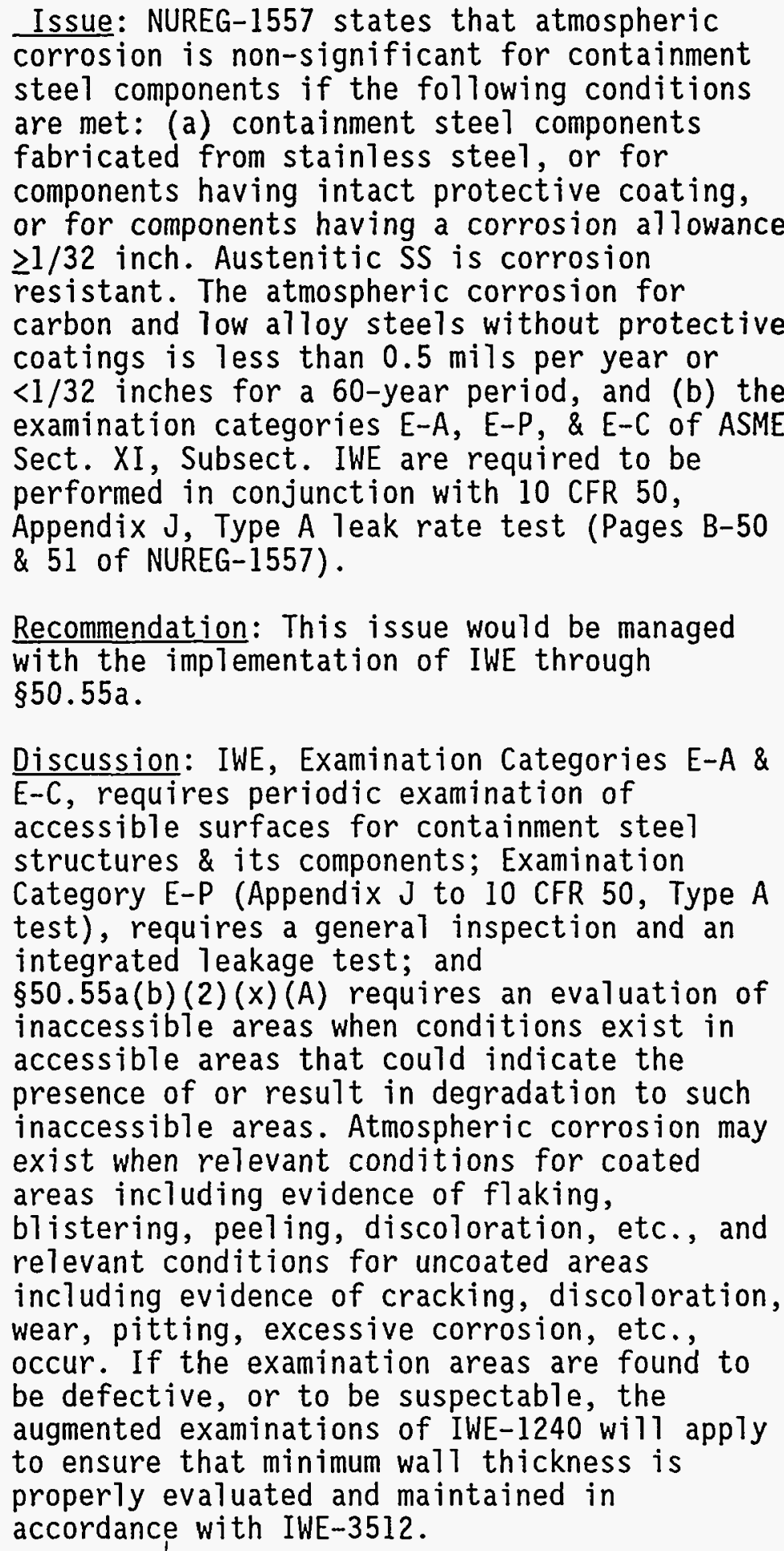 \\
\hline
\end{tabular}




\begin{tabular}{|c|c|c|}
\hline 09 & $\begin{array}{l}\text { Struct. Steel \& } \\
\text { Liner } \\
\text { Aging mechanism: } \\
\text { Local corrosion } \\
\text { Aging effects: } \\
\text { Loss of material }\end{array}$ & $\begin{array}{l}\text { Issue: (a) NUREG-1557 indicates that local } \\
\text { corrosion would be managed with the } \\
\text { implementation of IWE-1240 for steel } \\
\text { containment and its common components. NUREG- } \\
\text { l557 indicates that a plant-specific aging } \\
\text { program is required to manage the local } \\
\text { corrosion of steel containment inaccessible } \\
\text { areas and/or embedded carbon steel containment } \\
\text { components (Pages B-53 and B-55 of NUREG- } \\
\text { l557). (b) NUREG-1557 indicates that local } \\
\text { corrosion is non-significant for concrete } \\
\text { containment liners and anchors if the } \\
\text { following conditions are met: Corrosion of the } \\
\text { liner plate is mitigated by protective } \\
\text { coatings on the interior surface, and by the } \\
\text { alkaline environment between the exterior } \\
\text { surface of the liner plate and the concrete } \\
\text { structure. Stainless steel is corrosion } \\
\text { resistant (Pages B-54 of NUREG-1557). } \\
\text { Recommendation: All accessible areas would be } \\
\text { managed with implementing IWE through } 550.55 a . \\
\text { However, the management of potential local } \\
\text { corrosion of inaccessible areas of structural } \\
\text { steel and liner when conditions in accessible } \\
\text { areas may not indicate the presence of or } \\
\text { result in degradation to such inaccessible } \\
\text { areas needs to be justified on a plant- } \\
\text { specific basis. } \\
\text { Discussion: IWE, Examination Categories E-A, } \\
\text { E-C, E-D, and E-G, provides periodic } \\
\text { examination of accessible areas to uncover } \\
\text { structural degradation. This inspection would } \\
\text { detect local corrosion regardless whether the } \\
\text { conditions in (b) are met. IWE-1240 specifies } \\
\text { augmented inspections for areas likely to } \\
\text { experience accelerated degradation and aging. } \\
\text { \$50.55a(b) (2) (x) (A) requires an evaluation of } \\
\text { acceptability of inaccessible areas when } \\
\text { conditions exist in accessible areas that } \\
\text { could indicate the presence of or result in } \\
\text { degradation to such inaccessible areas. } \\
\text { However, the management of local corrosion of } \\
\text { inaccessible areas when conditions in } \\
\text { accessible areas may not indicate the presence } \\
\text { of or result in degradation to such } \\
\text { inaccessible areas needs to be evaluated. }\end{array}$ \\
\hline
\end{tabular}




\begin{tabular}{|c|c|c|}
\hline 10 & $\begin{array}{l}\text { Struct. Steel \& } \\
\text { Liner } \\
\text { Aging mechanism: } \\
\text { Elevated } \\
\text { temperature } \\
\text { Aging effects: } \\
\text { Loss of strength \& } \\
\text { modulus }\end{array}$ & $\begin{array}{l}\text { Issue: NUREG-1557 states that elevated } \\
\text { temperature is non-significant for PWR } \\
\text { containment structural steel and liner (Page } \\
\text { B-33 of NUREG-1557). However, NUREG-1557 does } \\
\text { not address elevated temperature effects on } \\
\text { BWR containment steel liner (Page B-56 of } \\
\text { NUREG-1557). } \\
\text { Recommendation: The issue is non-significant. } \\
\text { Discussion: Operating temperatures within BWR } \\
\text { containment structures are }\left\langle 66^{\circ} \mathrm{C}\left(150^{\circ} \mathrm{F} \text { ) which }\right.\right. \\
\text { are we11 below the } 316^{\circ} \mathrm{C}\left(600^{\circ} \mathrm{F} \text { ) level at }\right. \\
\text { which the structural integrity of } \\
\text { rebar/concrete combination begins to be } \\
\text { significantly affected. Thus the issue is non- } \\
\text { significant. This conciusion is al so } \\
\text { applicable to the BWR containment stee liner. }\end{array}$ \\
\hline 11 & $\begin{array}{l}\frac{\text { Struct. Steel \& }}{\text { Liner }} \\
\text { Aging mechanism: } \\
\text { Irradiation of } \\
\text { steel } \\
\text { Aging effects: } \\
\text { Loss of fracture } \\
\text { toughness }\end{array}$ & $\begin{array}{l}\text { Issue: NUREG-1557 states that irradiation of } \\
\text { steel is non-significant for containment } \\
\text { structural steel \& liner (Page B-57 of NUREG- } \\
\text { 1557). } \\
\text { Recommendation: The issue is non-significant. } \\
\text { Discussion: The neutron fluence levels \& } \\
\text { maximum integrated gamma doses incurred by } \\
\text { containment components, including containment } \\
\text { steel \& liners throughout the license renewal } \\
\text { period are not expected to exceed the level at } \\
\text { which measurable degradation occurs } \\
\text { ( } 2 \times 10^{17} \text { / } / \mathrm{cm}^{2} \text { for all components made of carbon } \\
\text { steel, stainless steel, and liner plate). Thus } \\
\text { the issue is non-significant. }\end{array}$ \\
\hline
\end{tabular}




\begin{tabular}{|c|c|c|}
\hline 12 & $\begin{array}{l}\text { Struct. Steel \& } \\
\text { Liner } \\
\text { Aging mechanism: } \\
\text { Stress corrosion } \\
\text { cracking (SCC) } \\
\text { Aging effects: } \\
\text { Crack initiation \& } \\
\text { growth }\end{array}$ & $\begin{array}{l}\text { Issue: (a) NUREG-1557 indicates that SCC is } \\
\text { non-significant for containment components, } \\
\text { including penetration sleeves, bellows, and } \\
\text { vent line bellows if the following conditions } \\
\text { are met: for austenitic SS containment } \\
\text { components that are only exposed to the } \\
\text { containment or reactor building environment or } \\
\text { their normal operational stress levels are } \\
\text { less than materials yield strength or fracture } \\
\text { mechanics analysis has established that cracks } \\
\text { do not propagate; and for high strength bolts } \\
\text { if material yield strength is <lo34 MPa(<150 } \\
\text { ksi) (b) SCC would be managed for suppression } \\
\text { chamber shell interior surface by implementing } \\
\text { lo CFR 50, Appendix J integrated leak rate } \\
\text { test to maintain liner integrity (Page B-63 of } \\
\text { NUREG-1557). } \\
\text { Recommendation: This issue would be managed by } \\
\text { Examination Categories E-B \& E-F of Subsection } \\
\text { IWE and Appendix J to lo CFR 50. In addition, } \\
\text { an augmented vT-1 visual examination of } \\
\text { bellows bodies should be performed using } \\
\text { enhanced techniques qualified for detecting } \\
\text { stress corrosion cracking in bellows bodies. } \\
\text { Discussion: IWE Examination Category E-F } \\
\text { provides periodic surface examination of } \\
\text { pressure retaining dissimilar metal welds for } \\
\text { dissimilar metals and could detect SCC. IWE, } \\
\text { Examination Category E-B, provides periodic } \\
\text { visual examination of pressure retaining welds } \\
\text { for containment penetrations. Also any leakage } \\
\text { associated with the steel liner, including } \\
\text { suppression pool liner, due to through-wal1 } \\
\text { cracks resulting from SCC would be detected by } \\
\text { periodic Appendix J leak rate test \& remains } \\
\text { within the limits of plant specifications or } \\
\text { Subsection IWE. Although §50.55a indicates } \\
\text { that Examination Categories E-B \& E-F are } \\
\text { optional during the current term of operation, } \\
\text { these examinations should be performed for } \\
\text { license renewal to demonstrate that no SCC has } \\
\text { been initiated. In addition, since occurrences } \\
\text { of transgranular stress corrosion cracking } \\
\text { have been identified in operating plants on ss } \\
\text { bellows [Reference 15], an augmented } \\
\text { examination on the surface areas of bellows } \\
\text { bodies should be performed so that cracking } \\
\text { would be detected. }\end{array}$ \\
\hline
\end{tabular}




\begin{tabular}{|c|c|c|}
\hline 13 & $\begin{array}{l}\frac{\text { Reinforcing Steel }}{(\text { Rebar) }} \\
\text { Aging mechanism: } \\
\text { Corrosion of } \\
\text { embedded steel } \\
\text { Aging effects: } \\
\text { Loss of bond \& loss } \\
\text { of material }\end{array}$ & $\begin{array}{l}\text { Issue: NUREG-1557 states that corrosion of } \\
\text { embedded steel is non-significant for concrete } \\
\text { structures not exposed to aggressive } \\
\text { environment (pH<l1.5 or chlorides >500 ppm); } \\
\text { or for concrete exposed to aggressive } \\
\text { environment but has relatively high strength } \\
\text { [27.6 MPa (4 ksi)] and low water-to-cement } \\
\text { ratio (0.35-0.45), adequate air entrainment } \\
\text { (3-6\%), 1ow permeability, and are designed in } \\
\text { accordance with ACI } 318 \text { or ASME Section III, } \\
\text { Division } 2 \text {. NUREG-1557 indicates corrosion of } \\
\text { embedded steel for concrete structures below } \\
\text { grade exposed to aggressive ground water (pH } \\
\text { <5.5, chloride >500 ppm, \& sulfate >1500 ppm) } \\
\text { should be examined in accordance with IWL and } \\
\text { management of inaccessible areas should be } \\
\text { justified on a case by case basis. Also the } \\
\text { NRC staff considers that potential degradation } \\
\text { due to chloride corrosion (e.g., ground water } \\
\text { chemical attack) of containments should be } \\
\text { addressed (Page B-52 of NUREG-1557). } \\
\text { Recommendation: The issue would be managed } \\
\text { with the implementation of IWL through } \\
\text { §50.55a. However, the management of potential } \\
\text { corrosion of inaccessible areas of embedded } \\
\text { steel when conditions in accessible areas may } \\
\text { not indicate the presence of or result in } \\
\text { degradation to such inaccessible areas needs } \\
\text { to be justified on a plant-specific basis. } \\
\text { Discussion: IWL, Examination Category L-A, } \\
\text { requires periodic examination of accessible } \\
\text { areas and §50.55a(b) ( } 2 \text { ) (ix) (E) requires an } \\
\text { evaluation of inaccessible areas when } \\
\text { conditions exist in accessible areas that } \\
\text { could indicate the presence of or result in } \\
\text { degradation to such inaccessible areas. } \\
\text { Corrosion of embedded steel results in } \\
\text { cracking and spalling of concrete and would be } \\
\text { detected by inspections, regardless of whether } \\
\text { the above conditions are met. However, the } \\
\text { management of potential corrosion of } \\
\text { inaccessible areas of embedded steel, when } \\
\text { conditions in accessible areas may not } \\
\text { indicate the presence of or result in } \\
\text { degradation to such inaccessible areas needs } \\
\text { to be evaluated. This would also address the } \\
\text { staff's concern on chloride corrosion. }\end{array}$ \\
\hline
\end{tabular}




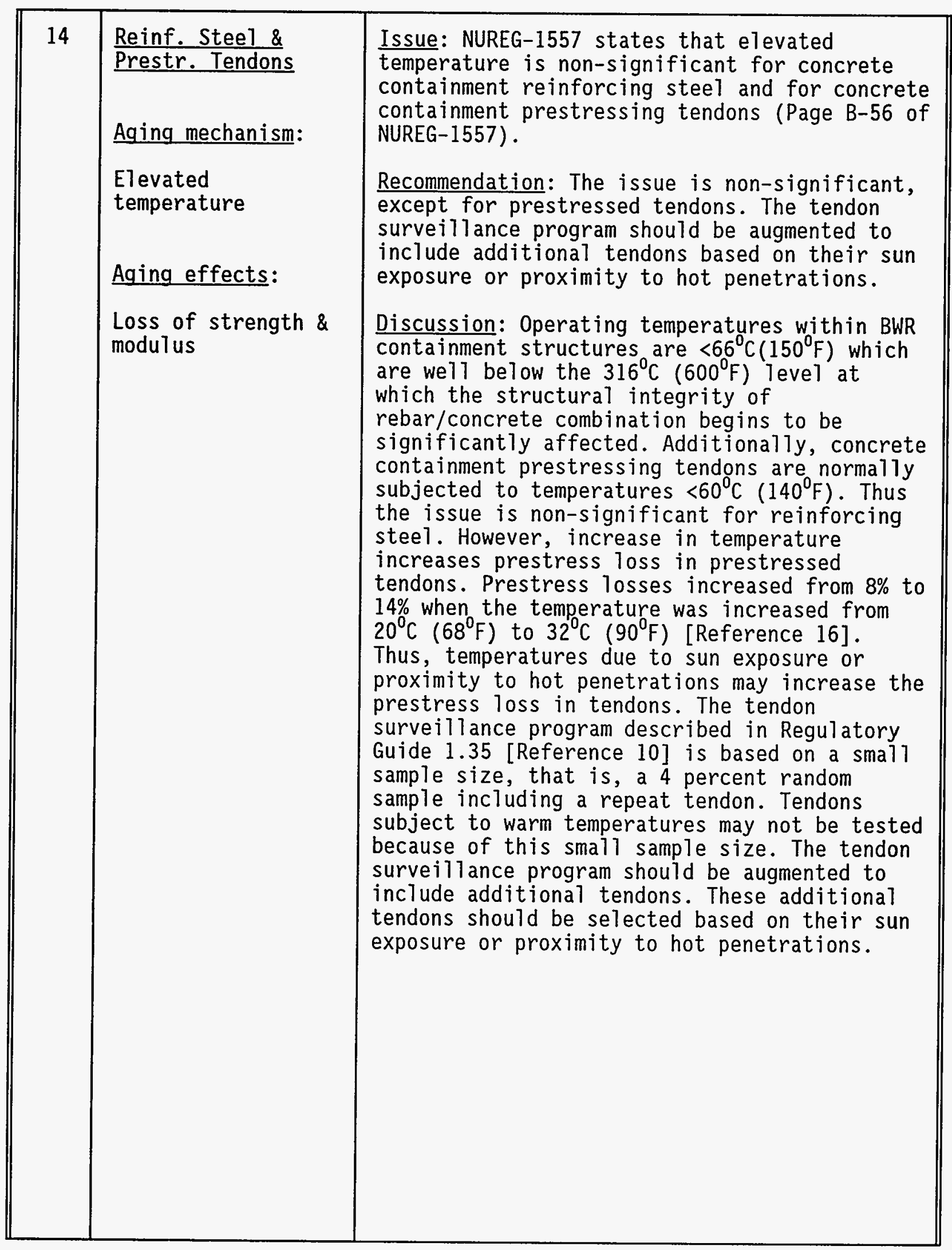




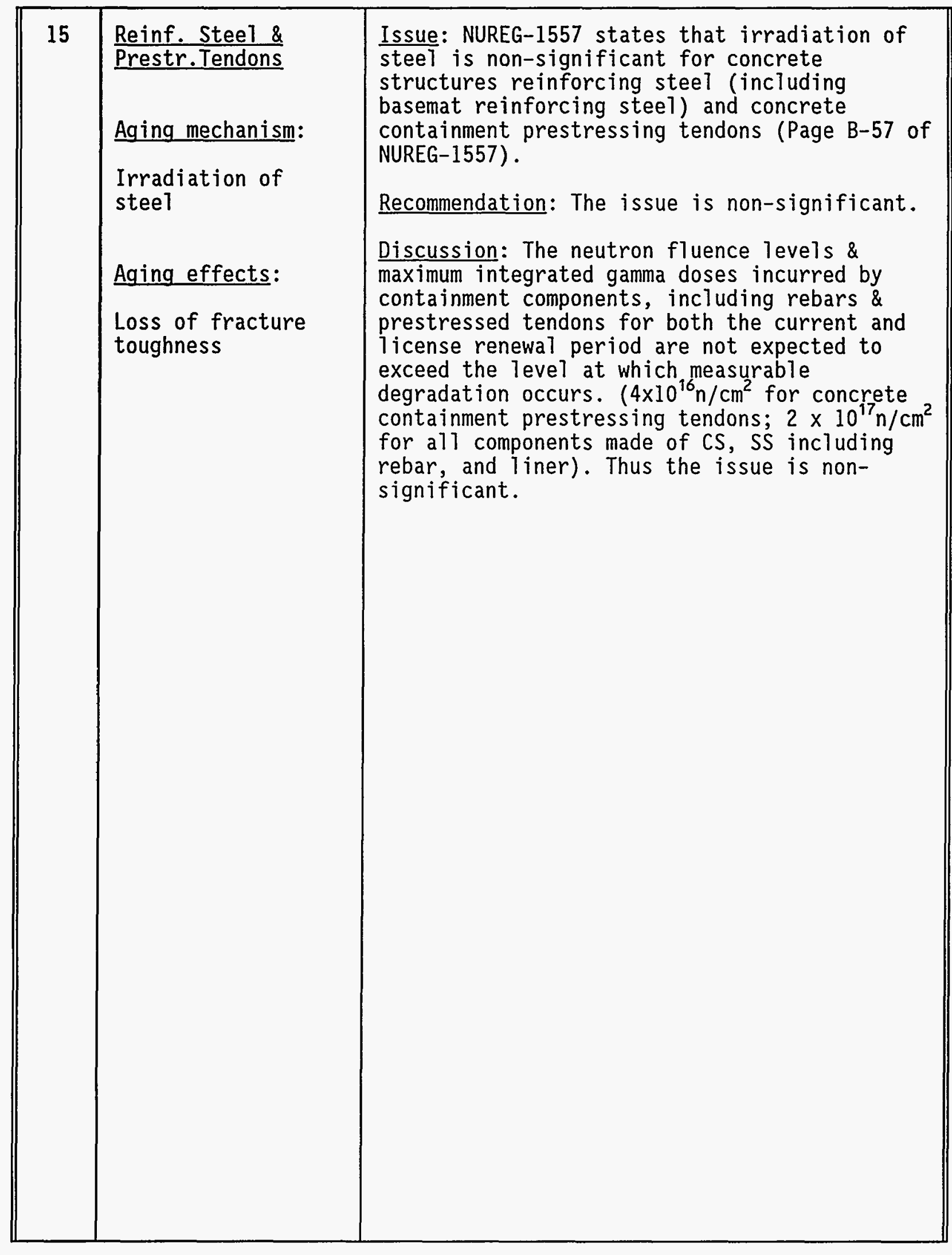




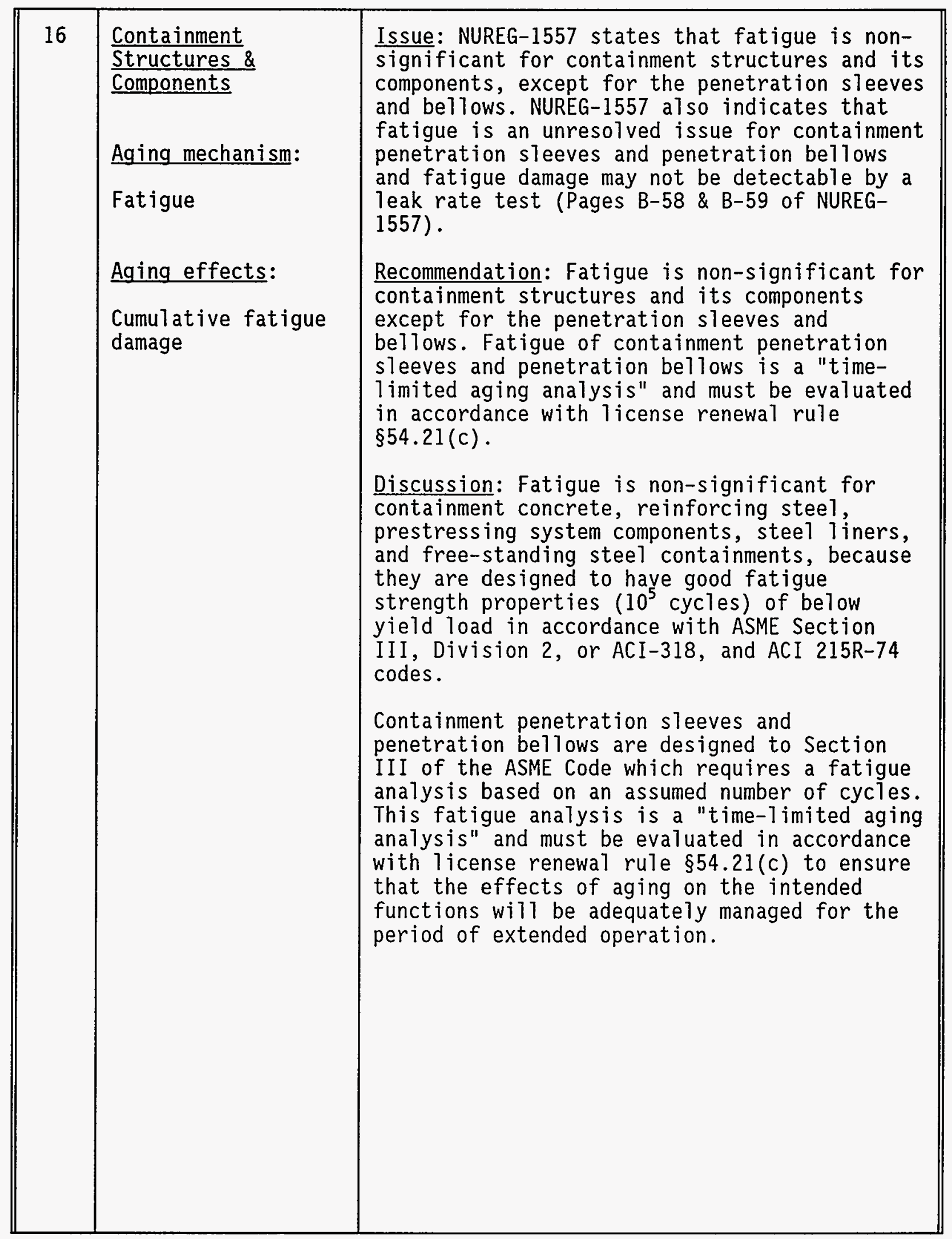




\begin{tabular}{|c|c|c|}
\hline 17 & $\begin{array}{l}\frac{\text { Containment }}{\text { Structure \& its }} \\
\text { Concrete Basemat } \\
\text { Aging mechanism: } \\
\text { Settlement } \\
\text { Aging effects: } \\
\text { Cracks, distortion, } \\
\text { increase in } \\
\text { component stress } \\
\text { leve1 }\end{array}$ & $\begin{array}{l}\text { Issue: NUREG-1557 indicates that for BWR } \\
\text { containment concrete basemat bearing on soil } \\
\text { or piles, or experiencing significant changes } \\
\text { in ground water conditions, a settlement } \\
\text { monitoring program is required to ensure that } \\
\text { the differential settlement does not exceed } \\
\text { the design criteria for the containment } \\
\text { throughout the Ticense renewal term (Page B-62 } \\
\text { of NUREG-1557). } \\
\text { Recommendation: The issue would be managed by } \\
\text { establishing a settlement monitoring program } \\
\text { which would ensure that differential } \\
\text { settlement of containment basemat does not } \\
\text { exceed the design criteria for a containment } \\
\text { structure and its basemat bearing on soil or } \\
\text { piles, or experiencing significant changes in } \\
\text { ground water conditions. } \\
\text { Discussion: Effects of differential settlement } \\
\text { are potentially significant for a containment } \\
\text { structure and its concrete basemat that is } \\
\text { resting on soil or piles, or experiencing } \\
\text { significant changes in ground water } \\
\text { conditions. Subsection IWL does not address } \\
\text { the effects of settlement. Because the effects } \\
\text { of settlement could cause cracks and } \\
\text { distortion of concrete basemat and could } \\
\text { result in increasing stress levels greater } \\
\text { than the original design basis in the basemat } \\
\text { and other parts of the containment structure. } \\
\text { A settlement monitoring program could ensure } \\
\text { that the differential settlement does not } \\
\text { exceed the design criteria for the containment } \\
\text { structures throughout the license renewal } \\
\text { term. A settlement monitoring program should } \\
\text { be provided to manage settlement for } \\
\text { containment basemat bearing on soil or piles, } \\
\text { or experiencing significant changes in ground } \\
\text { water conditions for the period of extended } \\
\text { operation. }\end{array}$ \\
\hline
\end{tabular}




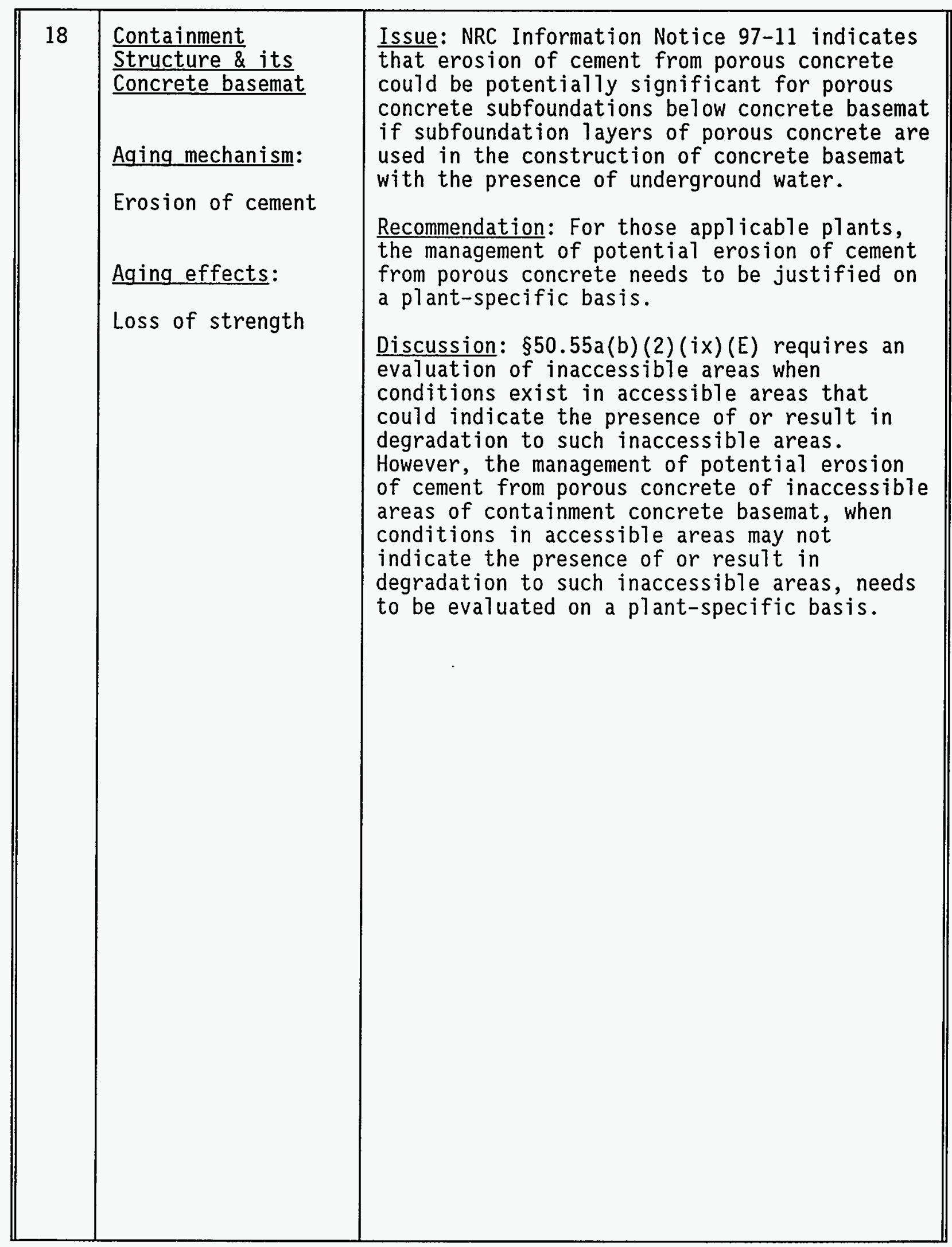




\begin{tabular}{|c|c|c|}
\hline 19 & $\begin{array}{l}\frac{\text { Containment }}{\text { Structure \& its }} \\
\text { Components } \\
\text { Aging mechanism: } \\
\text { Strain aging of } \\
\text { carbon stee1 } \\
\text { Aging effects: } \\
\text { Loss of fracture } \\
\text { toughness }\end{array}$ & 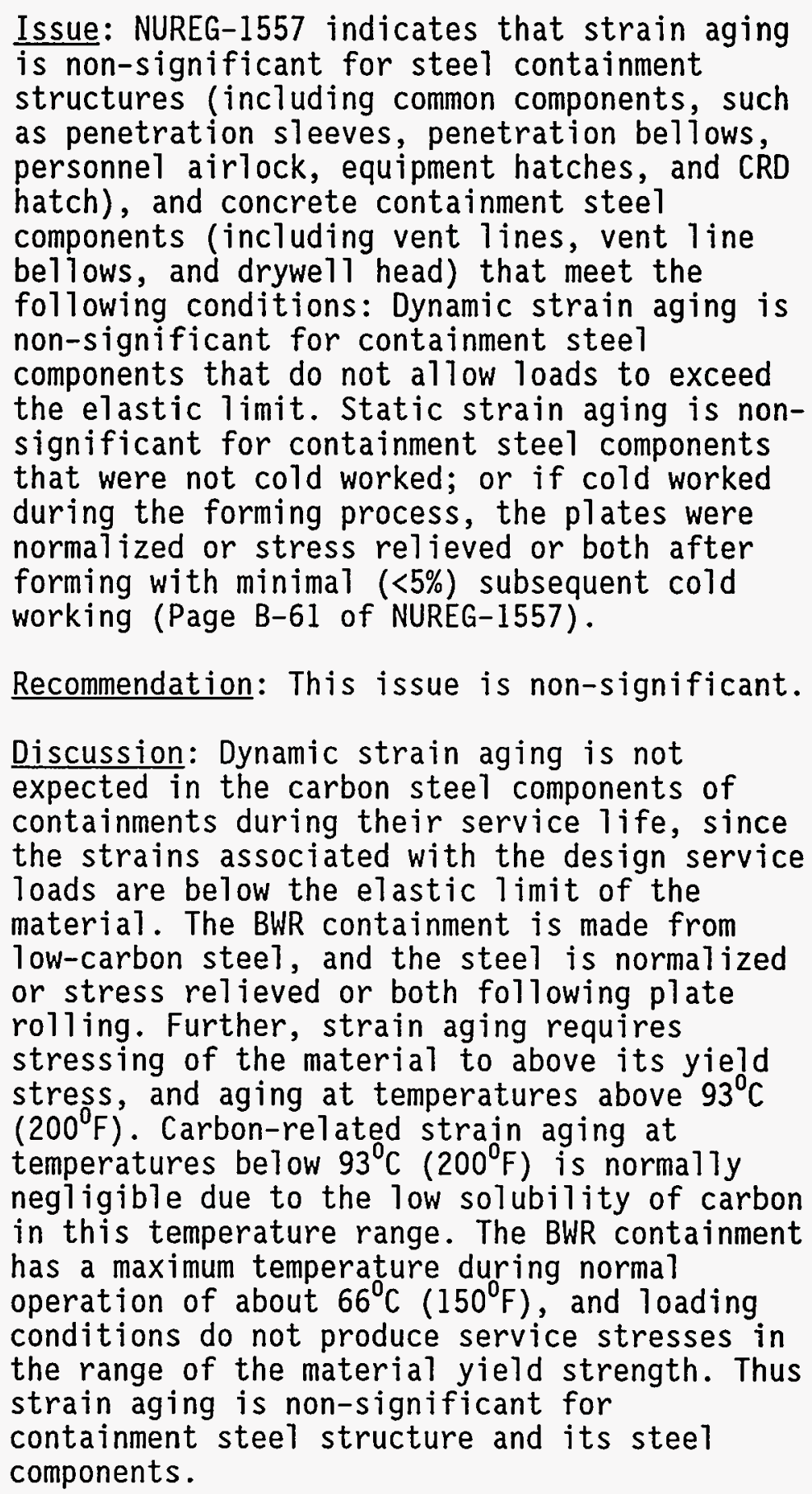 \\
\hline
\end{tabular}




\begin{tabular}{|c|c|c|}
\hline 20 & $\begin{array}{l}\text { Conc. Containment } \\
\text { Prestr. Tendons } \\
\text { Aging mechanism: } \\
\text { Stress relaxation } \\
\text { of prestressing } \\
\text { wire, shrinkage } \\
\text { creep, anchorage } \\
\text { seating losses, and } \\
\text { tendon friction } \\
\text { Aging effects: } \\
\text { Loss of prestress }\end{array}$ & 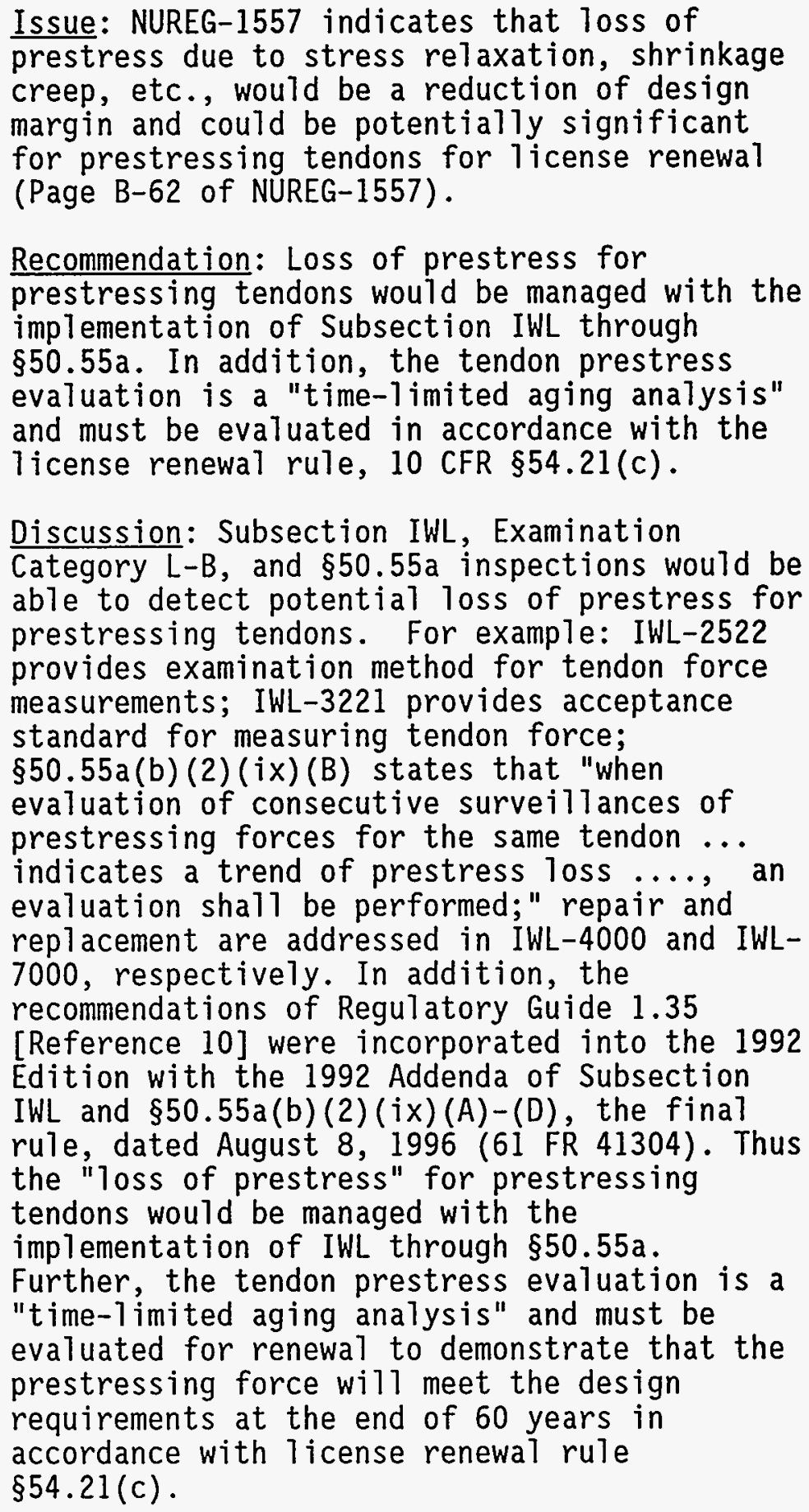 \\
\hline
\end{tabular}




\begin{tabular}{|c|c|c|}
\hline 21 & $\begin{array}{l}\text { Conc. Containment } \\
\text { Prestr. Tendons } \\
\text { Aging mechanism: } \\
\text { Corrosion of } \\
\text { tendons } \\
\text { Aging effects: } \\
\text { Loss of material }\end{array}$ & 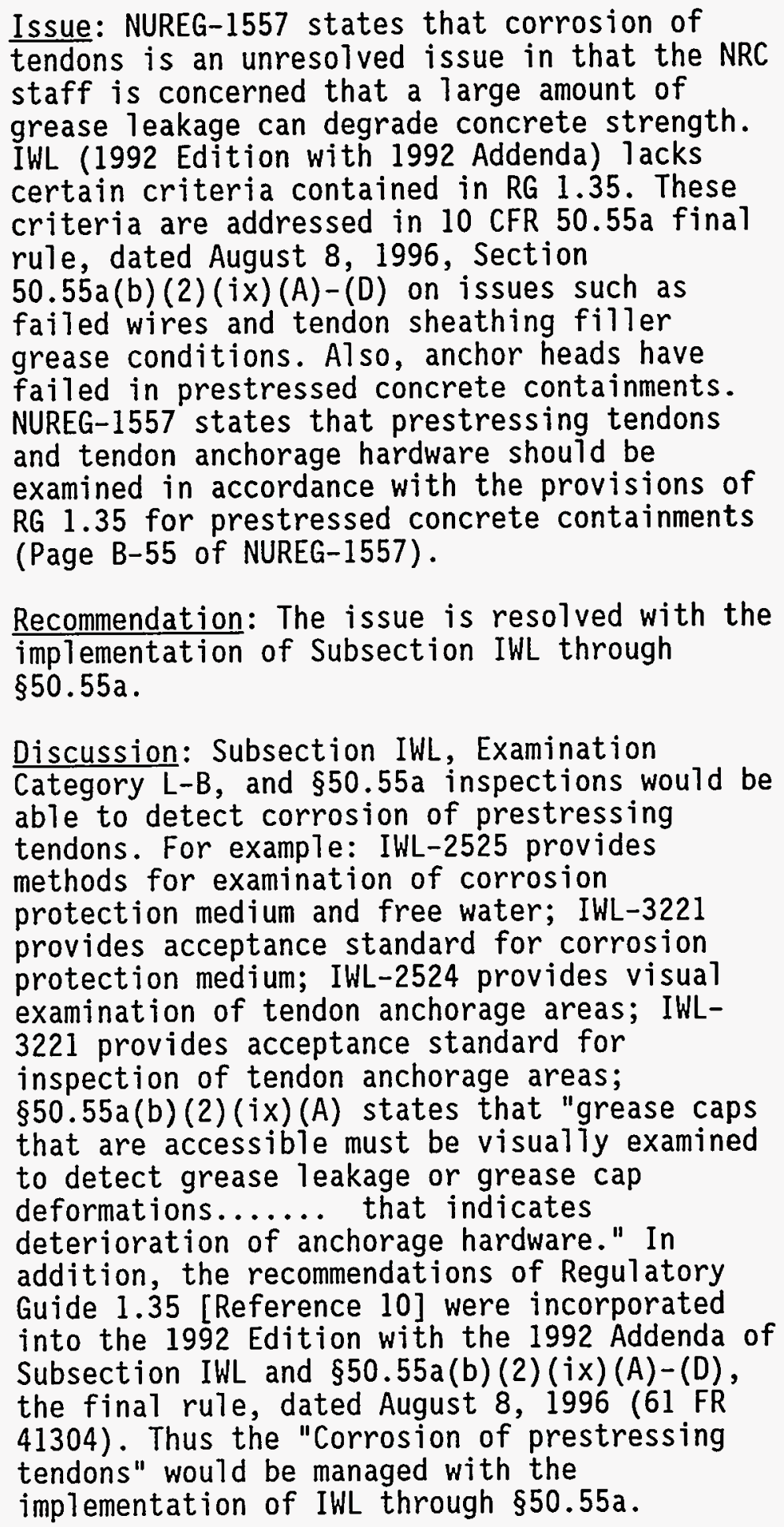 \\
\hline
\end{tabular}




\begin{tabular}{|c|c|c|}
\hline 22 & $\begin{array}{l}\frac{\text { Containment }}{\text { Pressure Retaining }} \\
\underline{\text { Components }} \\
\text { Aging mechanism: } \\
\text { Mechanical wear } \\
\text { Aging effects: } \\
\text { Fretting, Lockup }\end{array}$ & $\begin{array}{l}\text { Issue: Mechanical wear could be potentially } \\
\text { significant for components that are subject to } \\
\text { relative sliding or rotating motion and that } \\
\text { are susceptible to fretting and/or lockup. } \\
\text { (Page B-60 of NUREG-1557). } \\
\text { Recommendation: Mechanical wear for BWR } \\
\text { containment pressure retaining components \& } \\
\text { their supports would be managed with the } \\
\text { implementation of Subsections IWE and IWF. } \\
\text { Discussion: Inspection and mitigation of } \\
\text { mechanical wear conducted in accordance with } \\
\text { the provisions of Subsections IWE \& IWF would } \\
\text { ensure that the integrity of containment } \\
\text { pressure retaining components and their } \\
\text { supports is maintained throughout the license } \\
\text { renewal term. IWE, Examination Categories E-D } \\
\text { \& E-G, provides periodic examinations for the } \\
\text { pressure retaining components, (including } \\
\text { airlock, equipment hatch, CRD hatch \& drywell } \\
\text { head). IWE, Examination Category E-P (Appendix } \\
\text { J to Part 50, Type B test), would detect local } \\
\text { leaks for those components. The supporting } \\
\text { components such as downcomer bracing, column \& } \\
\text { saddle supports, seismic restraints \& vent } \\
\text { system supports are considered MC component } \\
\text { supports which are periodically examined by } \\
\text { Examination Category F-A of Subsection IWF. } \\
\text { Thus any potential mechanical wear degradation } \\
\text { would be detected by the implementation of IWE } \\
\text { and IWF for those pressure retaining } \\
\text { components and their supports. }\end{array}$ \\
\hline
\end{tabular}

* Evaluation is based on:

(1) the 1992 Edition with the 1992 Addenda of Subsections IWE and IWL of Section XI of the ASME Code;

(2) the 1989 Edition of Section XI of the ASME Code including Appendix VII, "Qualification of Nondestructive Examination Personnel for U1trasonic Examination," and Appendix VIII (1989 Addenda), "Performance Demonstration for U1trasonic Examination Systems;"

(3) the final rule on 10 CFR 50.55a, Codes and Standards, dated August 8, 1996 (61 FR 41303); and

(4) NUREG-1557, "Summary of Technical Information and Agreements from Nuclear Management and Resources Council Industry Reports Addressing License Renewal," dated October 1996.

Note (1) "Concrete interaction with aluminum" is not addressed in NUREG-1557 for BWR containment. However, this item is evaluated and considered not an issue for 7 icense renewal for PWR containment. Thus this item is considered not an issue for BWR containment. 


\section{APPENDIX A - IMPLEMENTATION HIGHLIGHTS OF SUBSECTIONS IWE AND IWL THROUGH 10 CFR 50.55a}

Subsection IWE provides rules for inservice inspection, repair, and replacement of Class MC pressure retaining components and their integral attachments and of metallic shell and penetration liners of Class CC pressure retaining components and their integral attachments in light-water cooled power plants. Subsection IWL provides rules for inservice inspection and repair of the reinforced concrete and the post-tensioning systems of Class CC components. Licensees will be required to incorporate Subsection IWE and Subsection IWL into their inservice inspection (ISI) program. Licensees will be required to implement the containment examinations in accordance with Subsections IWE and IWL as endorsed by $\$ 50.55$ a by September 9, 2001.

In endorsing Subsections IWE and IWL, 10 CFR 50.55a sets forth additional requirements to assure that the critical areas of containments are periodically inspected to detect and take corrective action for defects that could compromise a containment's structural integrity. These additional requirements include:

(a) Four modifications specified in $\$ 50.55 a(b)(2)(x)$ for examination of meta 7 containments and the liners of concrete containments. These are: (1) Section $50.55 a(b)(2)(x)(A)$ states that the licensee shall evaluate the acceptability of inaccessible areas of metal containments and the liners of concrete containments (Class MC), when conditions exist in accessible areas that could indicate the presence of or result in degradation to such inaccessible areas; (2) Section $50.55 a(b)(2)(x)(B)$ permits alternative lighting and resolution requirements for remote visual examination of the containment; (3) Section $50.55 \mathrm{a}(\mathrm{b})(2)(\mathrm{x})(\mathrm{C})$ makes the examination of pressure retaining welds and pressure retaining dissimilar metal welds optional; and (4) Section $50.55 a(b)(2)(x)(D)$ is added to provide an alternative sampling plan.

(b) Five modifications specified in $\$ 50.55 a(b)(2)$ (ix) for examination of concrete containments. These modifications must be implemented when using Subsection IWL. Four of these issues are identified in Regulatory Guide 1.35, Revision 3 , but are not addressed in the referenced Subsection IWL. The five modifications are: (1) Section $50.55 a(b)(2)(i x)(A)$ requires that grease caps which are accessible be visualiy examined to detect grease leakage or grease cap deformation; (2) Section $50.55 a(b)(2)(i x)(B)$ requires the preparation of an engineering evaluation report when consecutive surveillances indicate a trend of prestress loss to below the minimum prestress requirements; (3) Section $50.55 a(b)(2)(i x)(C)$ requires that an evaluation be performed for instances of wire failure and slip of wires in anchorages; (4) Section $50.55 a(b)(2)(i x)(D)$ addresses sampled sheathing filler grease and reportable conditions; and (5) Section 50.55a(b)(2)(ix)(E) requires that 1icensees evaluate the acceptability of inaccessible areas of concrete containments when conditions exist in accessible areas that could indicate the presence of or result in degradation to such inaccessible areas.

(c) One limitation specified in $\$ 50.55 \mathrm{a}(\mathrm{b})(2)(v i)$ for effective edition and addenda of Subsection IWE and Subsection IWL. It states that the 1992 Edition with the 1992 Addenda of Subsection IWE and Subsection IWL shall be used when 
performing containment examinations as modified and supplemented by the requirements described in $\$ 50.55 \mathrm{a}(\mathrm{b})(2)(\mathrm{ix})$ and $\$ 50.55 \mathrm{a}(\mathrm{b})(2)(\mathrm{x})$, respectively.

(d) One clarification specified in $\$ 50.55 \mathrm{a}(\mathrm{b})(2)(\mathrm{x})(\mathrm{E})$. It states that a general visual examination as required by Subsection IWE shall be performed once each period. 


\section{APPENDIX B - LIST OF PHR CONTAINMENT COMPONENTS}

\section{CONCRETE CONTAINMENTS (REINFORCED/PRESTRESSED)}

- Concrete Dome

- Dome Reinforcing Stee1

- Concrete Containment Wall Above Grade

- Containment Wall Reinforcing Steel Above Grade

- Concrete Containment Wall Below Grade

- Containment Wall Reinforcing Steel Below Grade

- Concrete Basemat

- Basemat Reinforcing Stee1

- Containment Liner Interior Surface

- Containment Liner Above Grade Exterior Surface

- Containment Liner Below Grade Exterior Surface

- Basemat Liner Interior Surface

- Basemat Liner Exterior Surface

- Liner Anchors Above Grade

- Liner Anchors Below Grade

2. FREE-STANDING STEEL CONTAINMENT WITH FLAT BOTTOM \& AN ICE CONDENSER

- Dome Shet7 Interior Surface

- Dome Shell Exterior Surface

- Cylindrical She17 Interior Surface

- Cylindrical Shell Exterior Surface

- Embedded She17 Region

- Concrete Basemat

- Basemat Reinforcing Steel

- Basemat Liner

- Liner Anchors

3. FREE-STANDING CYLINDRICAL \& SPHERICAL STEEL CONTAINMENT WITH ELLIPTICAL BOTTOM

- Containment Shell Interior Surface

- Containment Shell Exterior Surface

- Embedded She11 Region

- Sand Pocket Region

4. CONCRETE CONTAINMENTS PRESTRESSED ONLY

- Prestressing Tendons

5. COMMON COMPONENTS

- Penetration Sleeves

- Penetration Bellows

- Personnel Airlock

- Equipment Hatches

Reference:

Page B-45 of NUREG-1557, "Summary of Technical Information and Agreements from Nuclear Management and Resources Council Industry Reports Addressing License Renewal," dated October 1996. 


\section{APPENDIX C - LIST OF BWR CONTAINMENT COMPONENTS}

\section{MARK I CONCRETE CONTAINMENTS}

- Drywell Liner Interior Surface

- Drywell Liner Exterior Surface

- Torus Liner Interior Surface

- Torus Liner Interior Surface at Waterline

- Torus Liner Exterior Surface

- Liner Anchors

- Drywe11 Concrete

- Torus Concrete

- Drywel1 Concrete Reinforcing Steel

- Torus Concrete Reinforcing Steel

- Vent Lines

- Vent Line Bellows

- Vent Headers

- Downcomers and Bracing

- Vent System Supports

- Drywell Head

2. MARK I STEEL CONTAINMENTS

- Drywe11 Interior Surface

- Drywel1 Exterior Surface

- Drywel1 Head

- Embedded Shel1 Region

- Drywell Support Skirt

- Sand Pocket Region

- Torus Interior Surface

- Torus Interior Surface at Waterline

- Torus Exterior Surface

- Torus Ring Girder

- Vent Lines

- Vent Line Bellows

- Vent Header

- Downcomers and Bracing

- Drywell Exterior Shel1 with Compressible Material

- Vent System Supports

- Torus Seismic Restraints

- Torus Support Columns/Saddles

- ECCS Suction Header

- Ocean Plant with Uncoated CS Surfaces

- Uncoated Submerged CS Surfaces

\section{MARK II CONCRETE CONTAINMENTS}

- Drywell Liner Interior Surface

- Drywell Liner Exterior Surface

- Suppression Chamber Liner Interior Surface

- Suppression Chamber Liner Interior Surface at Wateriine

- Suppression Chamber Liner Exterior Surface

- Liner Anchors

- Liner Region Shielded by Diaphragm Floor

- Containment Concrete 
3. MARK II CONCRETE CONTAINMENTS (Continued)

- Concrete Containment Reinforcing Stee1

- Drywell Head

- Downcomer Pipes and Bracing

- Concrete Basemat

- Basemat Liner

- Basemat Reinforcing Stee1

- Prestressing Tendons and Ducts

\section{MARK II STEEL CONTAINMENTS}

- Drywell Interior Surface

- Drywell Exterior Surface

- Drywell Head

- Suppression Chamber Interior Surface

- Suppression Chamber Exterior Surface

- Suppression Chamber Interior Surface at Waterline

- Region Shielded by Diaphragm Floor

- Embedded Shell Region

- Sand Pocket Region

- Support Skirt

- Downcomer Pipes and Bracing

- Drywell Exterior Shell with Compressible Material

- Ocean PIant with Uncoated CS Surfaces

- Uncoated Submerged CS Surfaces

5. MARK III CONCRETE CONTAINMENTS

- Containment Liner Interior Surface

- Containment Liner Exterior Surface

- Suppression Chamber Liner or Cladding Interior Surface

- Suppression Chamber Liner Exterior Surface

- Concrete Containment Wall Above Grade

- Concrete Containment Wall Below Grade

- Concrete Dome

- Basemat Liner

- Concrete Basemat

- Liner Anchors

- Containment Wa11 Reinforcing Steel

- Dome Reinforcing Steel

- Basemat Reinforcing Stee1

6. MARK III STEEL CONTAINMENTS

- Containment Sheir Interior Surface

- Containment Shell Exterior Surface

- Suppression Chamber Shel1 Interior Surface

- Suppression Chamber Shell Exterior Surface

- Basemat Liner

- Liner Anchors

- Concrete Basemat

- Basemat Reinforcing Steel

- Concrete Fill in Annulus

- Embedded She11 Region 


\section{CONTAINMENT COMMON COMPONENTS}

- Penetration Bellows

- Penetration Sleeves

- Dissimilar Metal Welds

- Personnel Airlock

- Equipment Hatches

- CRD Hatch

\section{Reference:}

Pages B-65, B-53, and B-52 of NUREG-1557, "Summary of Technical Information and Agreements from Nuclear Management and Resources Council Industry Reports Addressing License Renewa?," dated October 1996. 


\section{TITLE AND SUBTITLE}

Aging Management of Nuclear Power Plant Containments for License Renewal

3. DATE REPORT PUBLISHED

4. FIN OR GRANT NUMBER

5. AUTHOR(S)

6. TYPE OF REPORT

W. C. Liu, P. T. Kuo, S. S. Lee

\section{Regulatory}

7. PERIOD COVERED (Inclusive Dales)

8. PERFORMING ORGANIZATION - NAME AND ADDRESS (INRC, provide Division, Office or Region, U.S. Nuclear Regulatory Commission, and mailing address; if contractor, provide name and mailing address.)

Division of Reactor Program Management

Office of Nuclear Reactor Regulation

U.S. Nuclear Regulatory Commission

Washington, DC 20555-0001

9. SPONSORING ORGANIZATION - NAME AND ADDRESS (If NRC, type "Sane as above"; if contracto, provide NRC Division, Office or Region, U.S. Nuclear Regulatory Commission, and mailing address.)

Same as 8 . above.

10. SUPPLEMENTARY NOTES

11. ABSTRACT (200 words or tess)

In 1990, the Nuclear Management and Resources Council (NUMARC), now the Nuclear Energy Institute (NEI), submitted for NRC review, the industry reports (IRs), NUMARC Report 90-01 and NUMARC Report 90-10, addressing aging management issues associated with PWR containments and BWR containments for license renewal, respectively. In 1996, the Commission amended 10 CFR 50.55a to promulgate requirements for inservice inspection of containment structures. This rule amendment incorporates by reference the 1992 Edition with the 1992 Addenda of Subsections IWE and IWL of the ASME Code addressing the inservice inspection of metal containments/liners and concrete containments, respectively. The purpose of this report is to reconcile the technical information and agreements resulting from the NUMARC IR reviews which are generally described in NUREG-1557 and the inservice inspection requirements of subsections IWE and IWL as promulgated in $\$ 50.55$ a for license renewal consideration. This report concludes that Subsections IWE and IWL as endorsed in $\$ 50.55 \mathrm{a}$ are generally consistent with the technical agreements reached during the IR reviews. Specific exceptions are identified and additional evaluations and augmented inspections for renewal are recommended. 